\title{
48. DATA REPORT: CRETACEOUS OSTRACODES FROM HOLES 761B AND 764A (WOMBAT PLATEAU) AND HOLES 762C, 763B, AND 763C (EXMOUTH PLATEAU)1
}

\author{
Renée Damotte ${ }^{2}$
}

\begin{abstract}
The Cretaceous ostracodes species recognized on Leg 122 represent elements of South Gondwanan faunistic province. In Lower and middle Cretaceous cores, ostracodes species present were originally described from South Africa and in cores from Deep Sea Drilling Project Leg 36 (Falkland Plateau): Arculicythere tumida, Bythocypris? cf. nodosa, "Bythocypris" cf. strogylae, Collosaboris? stanleyensis, Cytherella bensoni, Majungaella nematis, Robsoniella cf. falklandensis and Pirileberis aff. mkuzensis. In Upper Cretaceous levels, the Australian species Apateloschizocythere geniculata, Bairdia austracretacea, Cytherella cf. atypica, Cytherella cf. jonesi, Cytherelloidea $\mathrm{cf}$. carnarvonensis, Cytherelloidea cf. colemani, Karsteneis aspericava, and Trachyleberis anteplana were found.
\end{abstract}

\section{INTRODUCTION}

Examination of Cretaceous ostracodes from Holes 761B, 764A, Wombat Plateau, and 762C, 763B, and 763C, Exmouth Plateau, revealed rather poor fauna (see Fig. 1 for site map). The 5- to $10-\mathrm{cm}^{3}$ samples were washed on three screens (size $365 \mu \mathrm{m}, 160 \mu \mathrm{m}$, and $100 \mu \mathrm{m}$ ). The fossiliferous samples contain generally one to six specimens of each species. Numbers of species in each sample is given in Tables 1-4.

In the Lower Cretaceous (Hole 763C and the lower part of Holes 762B and 763B), we found the typical Gondwanan genera Arculicythere, Collisaboris, Majungaella, Mandawacythere, and Pirileberis, along with wide-ranging genera such as Bythocypris, Cytherella, Cytheropteron, Oligocythereis, and Robsoniella. In the Upper Cretaceous (Holes $761 \mathrm{~B}, 764 \mathrm{~A}$, and upper 762C and 763B), the Gondwanan genera Apateloschizocythere and Paramunseyella are present, together with several cosmopolitan genera, Bairdia, Cytherella, Cytherelloidea, Karsteneis, Krithe, and Trachyleberis.

\section{STRATIGRAPHIC INTERPRETATION}

The stratigraphic interpretation presented here is based on the occurrence of ostracodes in the Lower Cretaceous of South Africa, Madagascar, and DSDP Legs 25, 27, and 36 (Bate, 1975; Bate and Bayliss, 1969; Brenner and Oertli, 1976; Dingle, 1969a, 1971, 1984; Grekoff, 1963; Krömmelbein, 1975; McLachlan et al., 1976a; MacLachlan et al., 1976b; Oertli, 1974; Sigal, 1974) and in the Upper Cretaceous of western Australia and South Africa (Bate, 1972; Dingle, 1969b, 1980, 1981, 1981, 1985; Neale, 1974, 1975). With the exception of some work on South America (Bertels, 1974, 1975, 1977, 1988), no other data on Southern Hemisphere ostracodes were useful for this purpose.

Correlations with biostratigraphic results from calcareous nannofossils and planktonic foraminifers were established by using the Leg 122 Initial Reports (Haq, von Rad, O'Connell, et al., 1990).

\footnotetext{
1 von Rad, U., Haq, B. U., et al., 1992. Proc. ODP, Sci. Results, 122: College Station, TX (Ocean Drilling Program).

2 Unité Associée au Centre National de la Recherche Scientifique 1315 , Géotectonique et Stratigraphie, Laboratoire de Micropaléontologie, Université Pierre et Marie Curie, Paris 05, France.
}

In Hole 759B, Samples 122-759B-13R-1, 103-105 cm, $122-$ 759B-13R-2, 126-128 cm, and 122-759B-14R-2, 46-48 cm, are barren of ostracodes. In Hole 760A, Sample 122-760A-11X, 90-93 cm, and in Hole 760B, Sample 122-760B-13R-1, 72-74 $\mathrm{cm}$, likewise contain no ostracodes.

\section{Hole 761B}

In this hole, only samples of Unit IIB, nannofossil chalk, are fossiliferous in ostracodes (Table 1).

In Section 122-761B-24X-2, Paramunseyella? exmouthensis $\mathrm{n}$. sp. is present. This new species is described in Hole $762 \mathrm{C}$, Sections 122-762C-47X-4 through 122-762C-57X-2, thus indicating a Maestrichtian to Campanian range.

In Sections 122-761B-25X-2 through 122-761B-27X-1, the ostracode assemblage contains Apateloschizocythere geniculata, Cytherelloidea cf. carnarvonensis, and Trachyleberis anteplana. This association indicates a Campanian age according to Bate's (1972) data from the Carnarvon Basin of western Australia. The age dating is based on planktonic foraminifers; however, Bate lists no foraminiferal species names in his paper.

Nannofossil chalk was largely dated by nannofossils and foraminifers. In Hole 761B we recovered an apparently complete Maestrichtian-Campanian sequence. However, the remainder of the Upper Cretaceous appears to be punctuated by numerous hiatuses.

The nannofossil Maestrichtian NK18 Zone, between the base of Lithraphidites quadratus and the top of Broinsoina parca, is recognized in Sections 122-761B-23X-4 through $122-761 \mathrm{~B}-24 \mathrm{X}-4$. Sections 122-761B-24X-4 and 122-761B25X-1 are attributed to Maestrichtian Zone NK17, between the top of Broinsoina parca and the top of Reinhardtites levis. Sections $122-761 \mathrm{~B}-25 \mathrm{X}-1$ through $122-761 \mathrm{~B}-27 \mathrm{X}-1$ belong to Maestrichtian Zone NK16, between the top of Reinhardtites levis and the top of Eiffellithus eximius, and to part of Campanian Zone NK15, between the top of E. eximius and the base of Broinsoina parca. A hiatus lies near Section 122-761B$27 \mathrm{X}-1$, which is indicated by the close spacing of upper Campanian events, the first appearance of Quadratus gothicum, and lower Campanian and upper Santonian events, the first occurrence of Broinsoina (Aspidolithus) parca and Parhabdolithes regularis.

This hiatus includes much of the lower Campanian and upper Santonian (see Haq, von Rad, O'Connell, et al., 1990). 


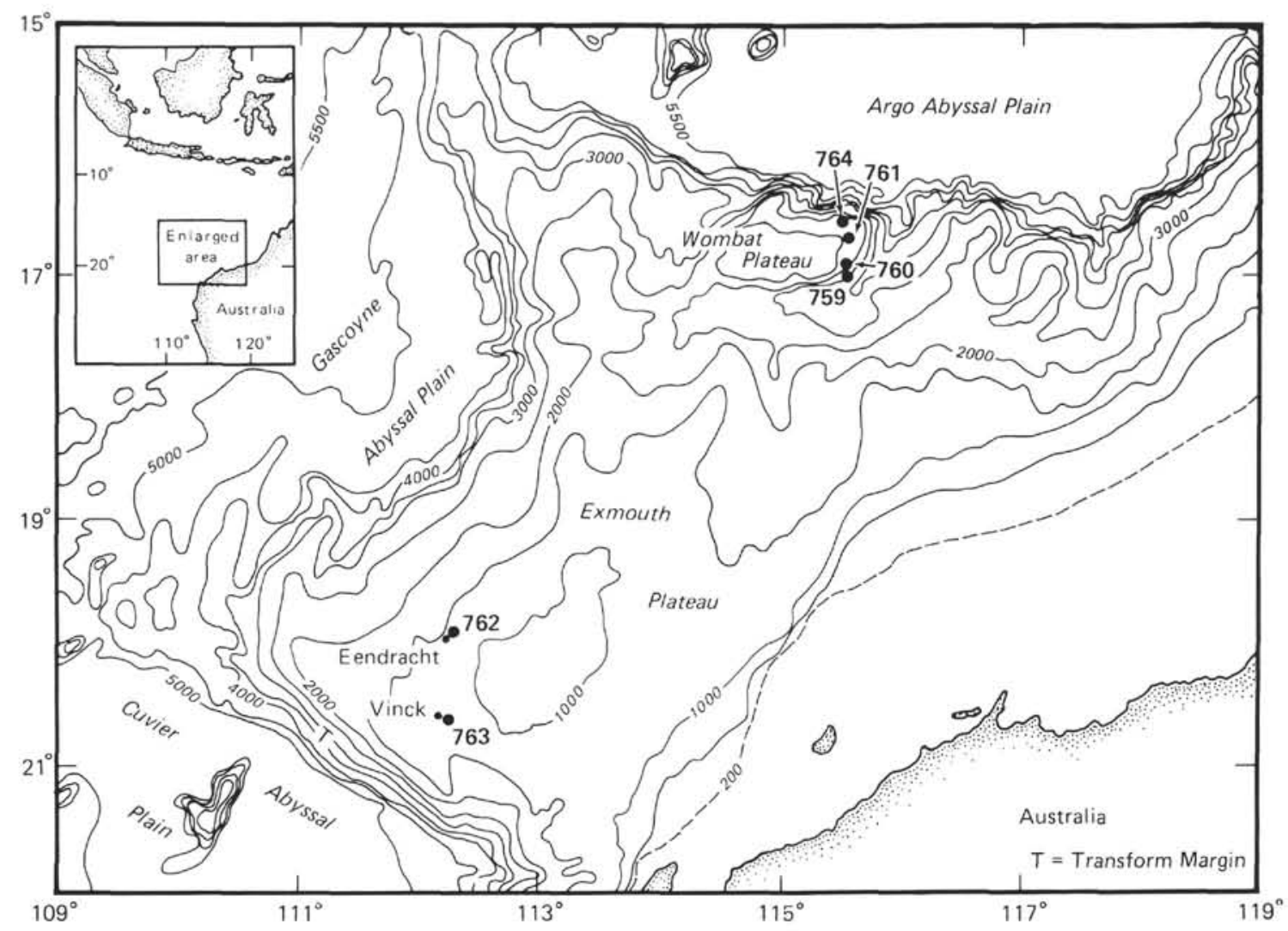

Figure 1. Location map of Leg 122 drill sites. Eendracht and Vinck are commercial exploration well sites. Bathymetry in meters.

According to foraminiferal occurrences, a Maestrichtian age is certain for Sample 122-761B-24X-4, 82-84 cm, which contains Abathomphalus intermedius and can be assigned to the Rosita contusa Zone. From the bottom of Core 122-761B$24 \mathrm{X}$ through Sample 122-761B-25X-3, 43-45 cm, a Ruggoglobigerina-dominated fauna is found, which is assigned a questionable Maestrichtian age on the strength of the presence of a primitive form of Gublerina sp. Below Section 122-761B$25 \mathrm{X}-\mathrm{CC}$, Gublerina is absent and an assemblage with Globotrunca ventricosa and $G$. elevata is present throughout Core 122-761B-26X. These species normally do not occur together, the former being an upper Campanian marker and the latter a lower Campanian marker; calcareous nannofossils suggest late Campanian age. A late Turonian age is indicated for Section 122-761B-27X-CC by the occurrence of Dicarinella imbricata and Falsotruncana maslakovae (see Haq, von Rad, O'Connell, et al., 1990).

Ostracodes indicate a probable Maestrichtian age for Section 122-761B-24X-2 and a Campanian age for Sections 122761B-25X-2 through 122-761B-27X-1. This agrees well with the ages obtained by nannofossils and foraminifers.

In Hole 761C, Sample 122-761C-5R-2, $54-56 \mathrm{~cm}$ is barren of ostracodes.

\section{Hole 762C}

In lithologic Unit IV (nannofossil chalk) Sample 122-762C$47 \mathrm{X}-4,63-65 \mathrm{~cm}$, contains the new species Paramunseyella? exmouthensis, Apateloschizocythere geniculata, and Eucytherura aff. pyramidatus (Table 2). Apateloschizocythere geniculata is described from the Campanian in western Australia, but Bate (1972) did not investigate Maestrichtian levels. In lithologic Unit IVb (nannofossil chalk with varying amounts of clay) these ostracodes are present in Sections 122-762C-49X-2 through Section 122-762C-58X-5: Apateloschizocythere geniculata, Cytherella cf. atypica, Cytherella cf. jonesi, Cytherelloidea cf. carnarvonensis, Karsteneis aspericava, Paramunseyella? exmouthensis, Genus X sp., and Krithe. This association indicates Campanian rather than Santonian age.

In Lithologic Unit IVc (very light greenish gray nannofossil chalk) ostracodes were found in Sections 122-762C-59X-4 through $122-762 \mathrm{C}-68 \mathrm{X}-1$. This fauna is relatively poor with few species: Cytherella cf. atypica, Cytherelloidea cf. carnarvonensis, Krithe sp., and Genus X sp., which indicate a Santonian-Campanian age. In Unit IVd (light greenish gray foraminifer-nannofossil chalk) only Sample 122-762C-77X-4, $17-19 \mathrm{~cm}$, yielded the stratigraphically useful ostracodes Arculicythere tumida, Cytherella bensoni, and Robsoniella cf. falklandensis. This association indicates an Albian age. Samples $122-762 \mathrm{C}-71 \mathrm{X}-1,62-64 \mathrm{~cm}$, and $122-762 \mathrm{C}-74 \mathrm{X}-1,74-76$ $\mathrm{cm}$, contain only Cytherella sp. and Krithe sp. In Unit IVe and $\mathrm{V}$, our samples are barren of ostracodes.

Using calcareous nannofossil stratigraphy (see Haq, von Rad, O'Connell, et al., 1990), Section 122-762C-47X-4 was placed in the Maestrichtian Zone NK18, between the base of Lithraphidites quadratus and the base of Arkhangelskiella cymbiformis. The interval between Sections 122-762C-49X-2 and 122-762C-58X-5 lies between Maestrichtian Zones NK17 and NK16, the top of Broinsoina parca to the top of Eiffellithus eximius, and Campanian Zone NK15, the top of $E$. eximius to the base of Bronsoina parca. The interval between Sections $122-762$ C-58X-5 and 122-762C-68X-1 was placed in the Campanian Zone NK15 and the Santonian Zones NK14, 
Table 1. Occurrences of ostracodes, Hole 761B.

\begin{tabular}{|c|c|c|c|}
\hline 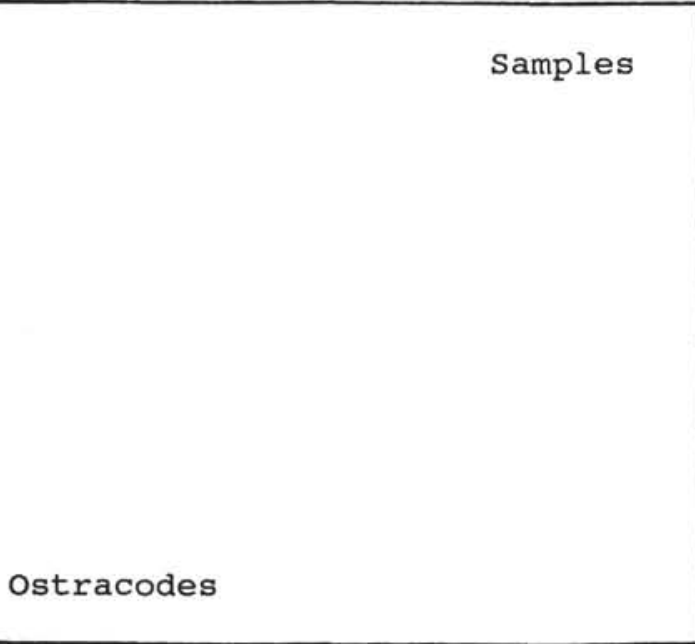 & 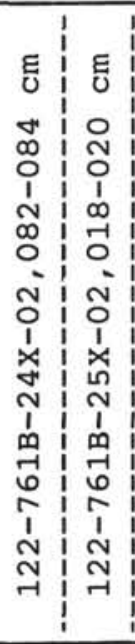 & 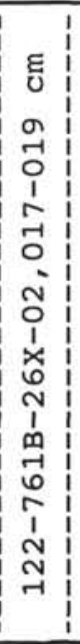 & 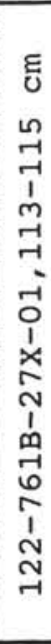 \\
\hline $\begin{array}{l}\text { Paramunsayella exmouthensis } \\
\text { Apateloschyzocythere geniculata } \\
\text { Trachyleberis anteplana } \\
\text { Cytherelloidea cf. carnavonensis } \\
\text { Hystricocythere? sp. }\end{array}$ & - & • & - \\
\hline
\end{tabular}

NK13, and NK12B, beginning with the base of Quadratum gothicum and reaching the top of Epolithus floralis. Section 122-762C-77X-4 belongs to the Albian Zone NK8, from the base of Eiffelithus turriseifelli to the base of Predicosphaera cretacea.

Using foraminifers (Haq, von Rad, O'Connell, et al., 1990), Sections 122-762C-43X-CC through 122-762C-46X-CC were assigned to the upper Maestrichtian Abatomphalus mayaroensis Zone and Section 122-762C-4X-CC to the Rosita contusa Zone. Lower down, Maestrichtian age is indicated by the presence of Gublerina spp. in Section 122-762C-53X-CC. In Section 122-762C-54X-CC downward, Gublerina was no longer found. Tentatively, the interval containing Globotruncana spp. and including $G$. arca, but lacking Dicarinella asymetrica, is attributable to the Campanian. An undifferentiated Santonian age is assigned to all sediments above the highest occurrence of Whiteinella archaeocretacea. This species appears in Section 122-762C-70X-CC and marks the top of a Coniacian to upper Turonian interval. This interval continues down to Sample 122-762C-73X-2, 50-52 cm. Sample $122-762 \mathrm{C}-75 \mathrm{X}-1,142-143 \mathrm{~cm}$, contains abundant Thalmanninella deeckei, which indicates a latest Cenomanian age. The Thalmanninella Zone may well be present in the sampling gap occupying most of Core 122-762C-77X. In Sample 122$762 \mathrm{C}-77 \mathrm{X}-4,50-52 \mathrm{~cm}$, the occurrence of Planomalina buxtorfi indicates the presence of Albian pelagic sediments.

According to nannofossil and foraminifer stratigraphical markers (Haq, von Rad, O'Connell, et al., 1990), the interval between Sections 122-762C-49X-2 and 122-762C-58X-5 is of Maestrichtian to Campanian age. The ostracode species present in this section are recorded from Campanian levels. But previous authors (especially Bate, 1972) did not investigate Maestrichtian levels. In the interval between Sections 122-
762C-59X-4 and 122-762C-68X-1, Santonian-Campanian age is indicated by all faunal groups. The Albian age of ostracode species in Sample 122-762C-77X-4, 17-19 cm, agrees well with nannofossil and foraminifer indications.

\section{Hole 763B}

In the chalky lithologic Unit III, ostracodes are present only in Cores 122-763B-8X to 122-763B-17X. Cores 122-763B18X through 122-763B-26X are barren of ostracodes. In lithologic Units IV and V, ostracodes are found only in Core 122-763B-27X and in Core 1222-763B-43X (Table 3).

In Sections 122-763B-8X-1 through 122-763B-14X-3, the ostracode association Cytherella jonesi and Bairdia austracretacea indicates a Campanian age, according to Bate (1972). In Sections 122-763B-16X-6 and 122-763B-17X-3, the two Campanian species Cytherella cf. atypica and Trachyleberis anteplana are present.

Calcareous nannofossil Zone NK15 has been assigned to Cores 122-763B-8X to 122-763B-8X. The Santonian-Campanian boundary is based on the first appearance of Broinsoina parca in Sample 122-763B-14X-CC (Haq, von Rad, O'Connell, et al., 1990). An upper Santonian-Coniacian hiatus lies in Section 122-763B-19X-1 or 122-763B-19X-2. The planktonic foraminiferal association Globotruncana arca, G. bulloides, and G. linneiana obliqua indicates an upper Campanian age for Sections 122-763B-8X-2 to 122-763B-11X-CC. In the interval between Sections 122-763B-12X-CC and 122$763 \mathrm{~B}-15 \mathrm{X}-\mathrm{CC}$, an undifferentiated Campanian age is preferred, as Globotruncana ventricosa has an extended range in the area. Santonian Marginotrunca assemblages are found from Sections 122-763B-16X-CC through 122-763B-18X-CC. Thus, there seems to be a good agreement between ages assigned by calcareous nannofossils, foraminifers, and ostra- 
Table 2. Occurrences of ostracodes, Hole 762C.

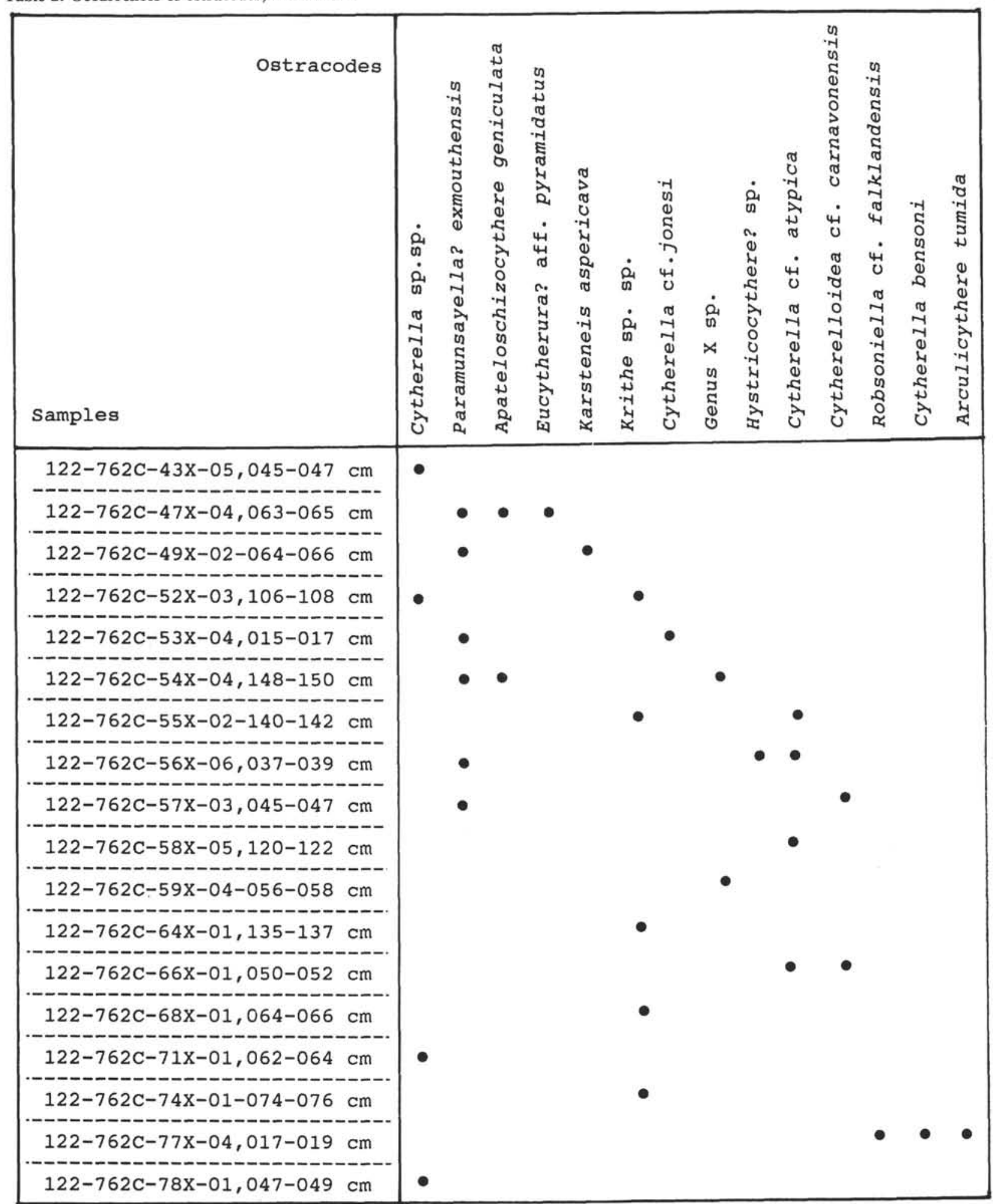

codes, except for Sections 122-763C-16X-6 and 122-763B$17 \mathrm{X}-3$, which are attributable to the Santonian according to the foraminifers, and to the lower Campanian according to ostracodes.

Cores 122-763B-18X through 122-763B-26X are barren of ostracodes. Collisobaris? stanleyensis is present in Sections
122-763B-27X-1 and 122-763B-29X-4. This is a middle to late Albian species according to Dingle (1984), who found it associated with Eiffellithus turriseiffelli and Predicosphaera cretacea in Leg 36 material. In Sections 122-763B-36X-3 and $122-763 \mathrm{~B}-34 \mathrm{X}-1$, the presence of Arculicythere tumida indicates an early middle Albian age (Dingle, 1984). 
Table 3. Occurrences of ostracodes, Hole 763B.

\begin{tabular}{|c|c|c|c|c|c|c|c|c|c|c|c|c|c|c|c|}
\hline 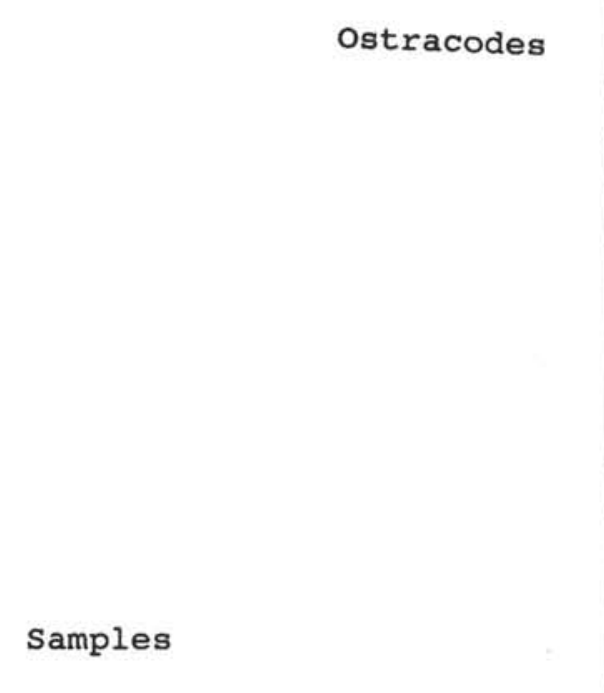 & 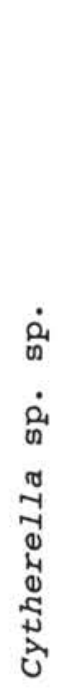 & 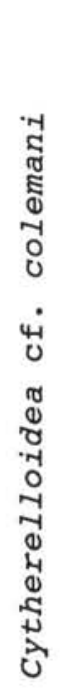 & 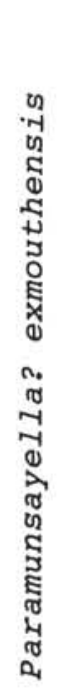 & 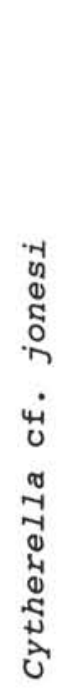 & 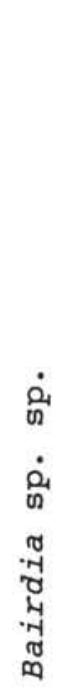 & 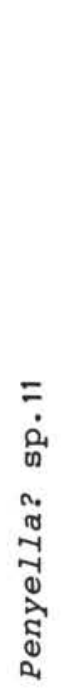 & 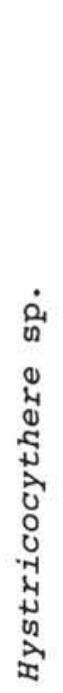 & 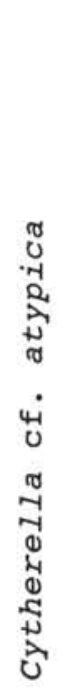 & 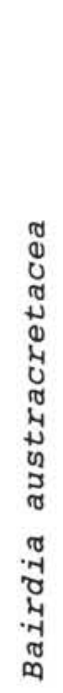 & 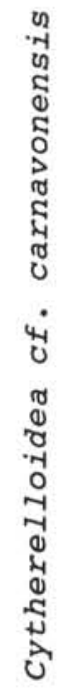 & 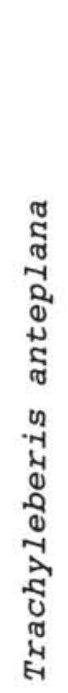 & 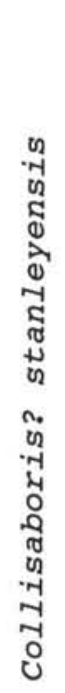 & 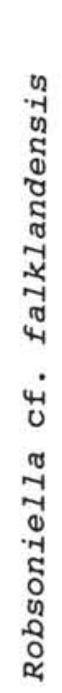 & 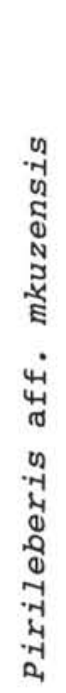 & 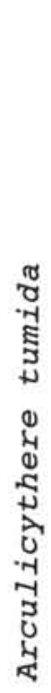 \\
\hline $\begin{array}{c}122-763 \mathrm{~B}-08 \mathrm{X}-01,088-090 \mathrm{~cm} \\
-122-763 \mathrm{~B}-09 \mathrm{X}-01,080-082 \mathrm{~cm} \\
-122-763 \mathrm{~B}-10 \mathrm{X}-01,080-082 \mathrm{~cm} \\
122-763 \mathrm{~B}-11 \mathrm{X}-02,049-051 \mathrm{~cm} \\
-122-763 \mathrm{~B}-13 \mathrm{X}-01,080-082 \mathrm{~cm} \\
122-763 \mathrm{~B}-14 \mathrm{X}-04,083-084 \mathrm{~cm} \\
122-763 \mathrm{~B}-15 \mathrm{X}-03,119-121 \mathrm{~cm} \\
122-763 \mathrm{~B}-16 \mathrm{X}-06,015-017 \mathrm{~cm} \\
122-763 \mathrm{~B}-27 \mathrm{X}-01,038-040 \mathrm{~cm} \\
-122-763 \mathrm{~B}-27 \mathrm{X}-03,038-040 \mathrm{~cm} \\
-122-763 \mathrm{~B}-29 \mathrm{X}-01,090-092 \mathrm{~cm} \\
122-763 \mathrm{~B}-29 \mathrm{X}-04,090-093 \mathrm{~cm} \\
122-763 \mathrm{~B}-36 \mathrm{X}-03,071-073 \mathrm{~cm} \\
122-763 \mathrm{~B}-36 \mathrm{X}-05,071-073 \mathrm{~cm} \\
122-763 \mathrm{~B}-37 \mathrm{X}-05,146-148 \mathrm{~cm} \\
122-763 \mathrm{~B}-38 \mathrm{X}-01,038-041 \mathrm{~cm} \\
122-763 \mathrm{~B}-39 \mathrm{X}-01,088-090 \mathrm{~cm}\end{array}$ & - & & $\bullet$ & • & $\bullet$ & $\bullet$ & - & $\bullet$ & $\bullet$ & $\bullet$ & $\bullet$ & $\bullet$ & $\bullet$ & $\bullet$ & $\bullet$ \\
\hline
\end{tabular}

Using calcareous nannofossil occurrences, the interval between Sections 122-763B-25X-CC and 122-763B-30X-CC belongs to the Cenomanian-Albian NK9A Zone, from the base of Lithraphidites acutum to the base of Eiffelithus turriseiffelli. The interval between Sections 122-763B-31X-CC and 122-763B-35X-CC belongs to the Albian NK8 Zone and the interval between Sections 122-763B-36X-CC and 122-763B-
41X-CC to the Albian-Aptian NK7 Zone, between the base of Predicosphaera cretacea and the base of Parhabdolithus angustus.

Sections 122-763B-27X-CC and 122-763B-28X-CC contain a double-keeled foraminifer Planomalina buxtorfi, indicating a late Albian age (Vraconian). In Sections 122-763B29X-CC down to 122-763B-36X-CC, Hedbergella planispira 
Table 4. Occurrences of ostracodes, Hole 763C.

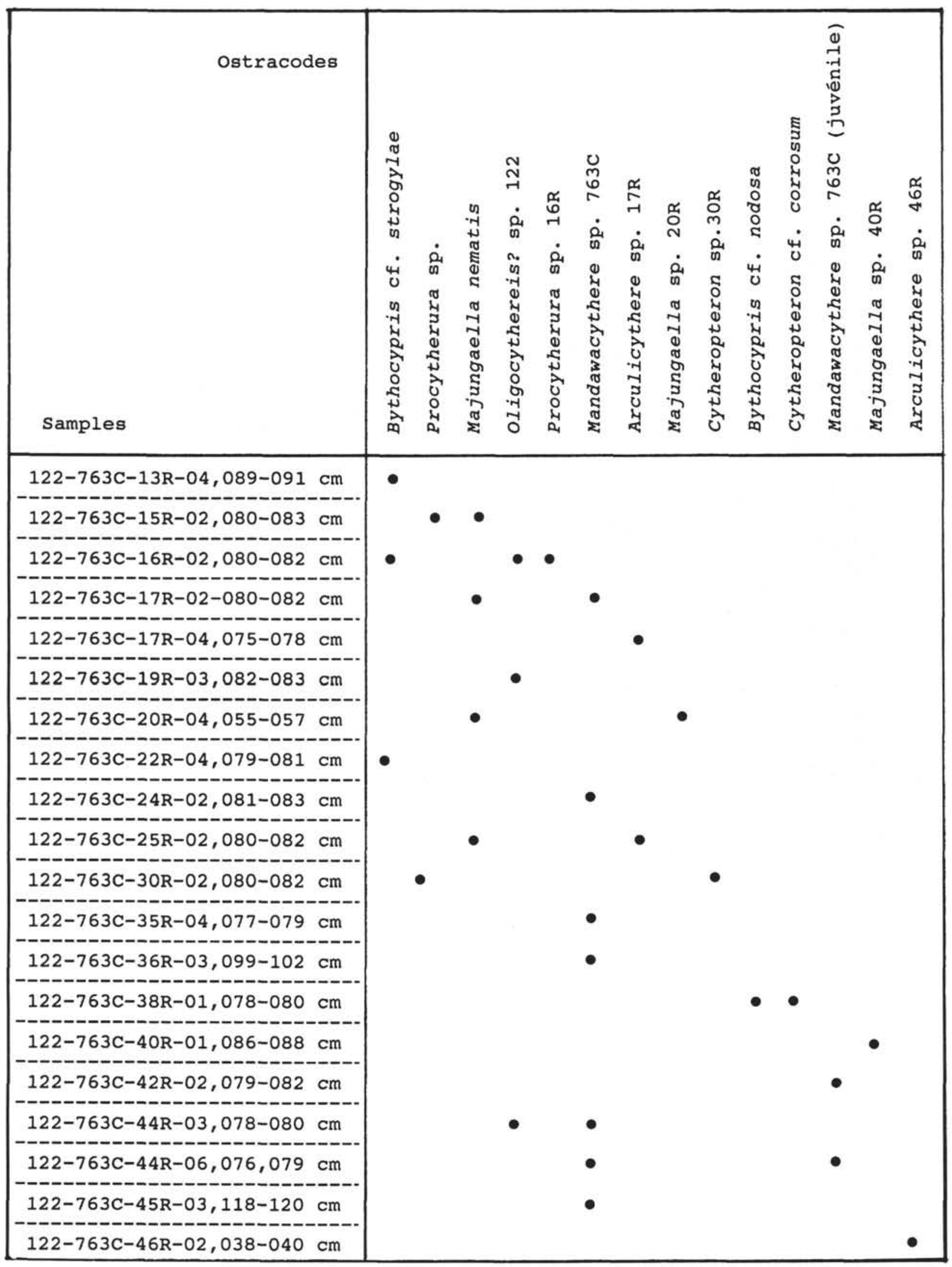


and Hedbergella delrioensis are present, accompanied by the benthic species Osangularia ex gr. utaturiensis and an occasional Gyroidinoides crassa. This fauna is not inconsistent with an Albian age although an Aptian age can also be assigned.

The ages indicated by the study of ostracodes agrees with the calcareous nannofossil and foraminifer stratigraphy.

\section{Hole 763C}

In lithologic Unit VII (Barrow Group), ostracodes are present in Sections 122-763C-13R-2 through 112-763C-45R-6 (Table 4). Majungaella nematis is present in Sections 122763C-13R-2 through Section 122-763C-25R-4. Grekoff (1963) describes it in the Portlandian-Valanginian of Madagascar. According to Grekoff the lower Portlandian levels contain Virgartosphinctes and Aulacosphinctes, the upper Portlandian levels Berriasella privascensis, and the Valanginian levels Duvalia and belemnites. Dingle (1984) recorded Majungaella nematis with the same stratigraphic distribution in South Africa, India, and the Mozambique Ridge (DSDP Leg 25). This species, however, extends into the Aptian and Cenomanian in Zululand, South Africa. In the same interval, Sections 122-763C-13R-4 through 122-763C-20R-4, "Bythocypris"' cf. strogylae is present. This species is described in Hauterivian levels from the Sunday River Formation, Algoa Basin, South Africa. In Section 122-763C-38R-4, Bythocypris? cf. nodosa, another South African Hauterivian species, is present. In Section 122-763C-38R-1, Eocytheropteron cf. corrosum, a South African Valanginian form (Maclachlan et al., 1976), is also present. These data could indicate a Valanginian-Hauterivian age for the interval between Sections 122-763C-13R-4 to $122-763$ C-38R-4; also, Section 122-763C-13R-2 may be younger.

Calcareous nannofossils in Sections 122-763C-6R-CC to $122-763 \mathrm{C}-12 \mathrm{R}-\mathrm{CC}$ are late Tithonian to middle Berriasian in age based on the occurrence of an early form of Umbria granulosa subsp. granulosa. In the interval between Cores 122-763C-19R and 122-763C-20R, well-preserved assemblages lack characteristic Berriasian and Tithonian markers and contain some very rare and possibly undescribed forms of the genus Stradnerlithus. This interval is characterized by low ratios of Watznaueria barnesae to various species of Ellipsagelosphaera; however, there is insufficient data to ascribe a Tithonian age to this interval (Haq, von Rad, O'Connell, et al., 1990).

In the Barrow Group, foraminiferal fauna are exclusively benthic, with three fossiliferous intervals separated by poor to barren sections. A fossiliferous interval extends from Sections $122-763 \mathrm{C}-14 \mathrm{R}-\mathrm{CC}$ to $122-763 \mathrm{C}-25 \mathrm{R}-\mathrm{CC}$, which contains the agglutinated foraminifers Haplophragmoides and Trochammina spp. In Sections 122-763C-14R-CC and 122-763C16R-CC Epistomina aff. E. caracolla are recorded. The presence of Epistomina caracolla itself would indicate Valanginian or Berriasian age. This agrees with the presence of Majungaella nematis in the same interval (Sections 122-763C15R-2 and 122-763C-17R-2). In the interval from Section 122-763C-29R-CC to Section 122-763C-46R-CC, none of the foraminifers encountered were age significant.

According to the evidence of dinoflagellates, the lower part of lithologic Unit VII below Core $122-763 \mathrm{C}-9 \mathrm{R}$ is middle to late Berriasian in age, belonging to the lower part of the Batoladinium zone and the Dissimulidinium zone. The age of the lithologic Unit VIII, based on the various microfossil groups, is summarized as follows: early Berriasian (late Tithonian?) to late Berriasian. Because of the lack of well-defined ostracode species, except for Majungaella nematis, precise stratigraphic information cannot be provided.

\section{Hole 764A}

In lithologic Unit III (nannofossil chalk), one sample, 122-764A-5R-4, 64-66 cm, contains two ostracodes species: Paramunseyella? exmouthensis and Karsteneis aspericava. These two species indicate a Campanian age but a Maestrichtian age cannot be excluded.

In Sample 122-764A-5R-3, 55-56 cm, nannofossils indicate an upper Campanian NK15B Zone. The planktonic foraminifers indicate that the Abathomphalus mayaroensis Maestrichtian Zone is represented in Section 122-764A-5R-CC.

These data attribute a very similar age to the cited sections.

\section{ECOLOGICAL INTERPRETATION OF OSTRACODE ASSEMBLAGES}

In Hole 761B, Cores 122-761B-24X through 122-761B-27X, the presence of Cytherelloidea and Trachyleberis may indicate a relatively deep-water environment from the outer shelf to upper slope. This agrees with the pelagic Albian to lower Maestrichtian environment quoted in Haq, von Rad, O'Connell, et al. (1990).

In Hole $762 \mathrm{C}$, Cores $122-762 \mathrm{C}-47 \mathrm{X}$ through $122-762 \mathrm{C}$ $68 \mathrm{X}$, the association of the ostracode genera Cytherella, Cytherelloidea, and Krithe suggests a deep-water environment, which agrees with the pelagic environment indicated in Haq, von Rad, O'Connell, et al. (1990). In Sample 122-762C$77 \mathrm{X}-4,17-19 \mathrm{~cm}$, the presence of Arculicythere tumida indicates a shallow-marine environment, according to Dingle (1984), in whose opinion Arculicythere tumida is a shallowwater form.

In Hole 763B, Cores 122-763B-8X through 122-763B-14X, the association of ostracode genera Bairdia and Cytherella suggests a deep marine environment. It seems to be the same environment suggested in Cores 122-763B-16X and 122-763B17, where Trachyleberis is also present.

In the Barrow Group, Cores 122-763C-13R through 122$763 \mathrm{C}-45 \mathrm{R}$, the association of "Bythocypris," Eocytheropteron, Majungaella, and Procytherura indicates a shallow-marine, infralittoral to intertidal environment (due to the presence of Cytherurinae). This paleoenvironment agrees with that indicated by foraminifers.

In Hole 764A, Core 122-764A-5R, ostracode fauna is restricted to Cytherella, Karsteneis, and Paramunsayella, which suggests an outer neritic to light pelagic deposit, but more precise information is absent.

\section{SYSTEMATIC DESCRIPTION}

The type specimens of new species and the illustrated specimens are deposited in the collections from the Laboratoire de Micropaleontologie, Université Pierre et Marie Curie, in Paris, France.

The familial classification used is generally the classification of Hartmann and Puri (1974). Taxonomic lists include all known references, but most of the species are recorded in few previous works.

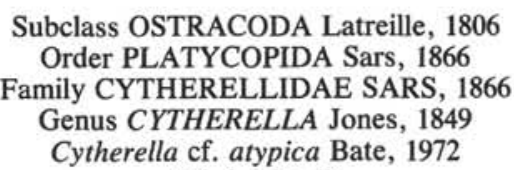
(Pl. 1, Fig. 1)

Cytherella atypica Bate, 1972, p. 4, pl. 3, figs. 1-4.

Length. 0.82-0.96 mm.

Occurrences. Cytherella atypica is described from the Campanian Toolonga calcilutite (Carnarvon Basin, western Australia),

Occurrences in Leg 122. Samples 122-763B-13X-1, 80-82 cm; $122-763 \mathrm{~B}-15 \mathrm{X}-3,19-21 \mathrm{~cm} ; 122-763 \mathrm{~B}-16 \mathrm{X}-6,15-17 \mathrm{~cm} ; 122-762 \mathrm{C}-$ $55 \mathrm{X}-6,140-142 \mathrm{~cm} ; 122-762 \mathrm{C}-64 \mathrm{X}-1,135-137 \mathrm{~cm}$. 
Cytherella bensoni Dingle, 1984

(Pl. 1, Fig. 2)

Cytherella bensoni Dingle, 1984, p. 110, figs. 5A, -B.

Length. $0.84 \mathrm{~mm}$.

Short description and remarks. Carapace subquadrate, broadly rounded anteriorly. Posterior part with weakly developed longitudinal ridges and with light reticulation. The anterior part possesses very weak reticulation. Dingle did not indicate such ridges, but they can be observed on his figure 5B. Hence, I think that this form can be conspecific with that described by Dingle.

Occurrences. Cytherella bensoni was described in the lower to middle Albian from DSDP Leg 36, Sites 327 and 330, Falkland Plateau.

Occurrences in Leg 122. Sample 122-762C-77X-4, 17-19 cm.

\section{Cytherella cf. jonesi Neale, 1975}

(PI. 1, Fig. 3)

Cytherella sp. Type B Bate, 1972, p. 8, pl. 3, fig. 5 .

Cytherella jonesi Neale, 1975, p. 4, pl. 3, figs. 1-3.

Length. $0.65-0.70 \mathrm{~mm}$.

Remarks. Our specimens are rather smaller than those of Neale $(0.82-0.86 \mathrm{~mm})$, but the others characteristics are quite similar.

Occurrences. This species was described by Neale in the Santonian Gingin chalk (western Australia), Bate found it in Santonian Toolonga calcilutite and in Campanian Korojon calcilutite (Carnarvon Basin, western Australia).

Occurrences in Leg 122. Samples 122-762C-53X-4, 15-17 cm; $122-762 \mathrm{C}-57 \mathrm{X}-3,45-47 \mathrm{~cm}$; 122-763B-9X-1, 80-82 cm; 122-763B$10 \mathrm{X}-1,80-82 \mathrm{~cm}$.

Genus CYTHERELLOIDEA Alexander, 1929

Cytherelloidea cf. carnarvonensis Bate, 1972

$$
\text { (PI. 1, Fig. 4) }
$$

Cytherelloidea carnarvonensis Bate, 1972, p. 14, pl. 2, figs. 4-9.

Length. $0.80-0.74 \mathrm{~mm}$.

Remarks. In Bate's description, shell surface is ornamented by rather large oval pits subdivided by smaller pits, and between peripheral furrows and margin by wrinkles parallel to the valve's edge. In those specimens, wrinkles are present on the entire shell surface. We see similar features on Bate's figure 8, plate 2. Thus, we think that our specimens are conspecific with Bate's species.

Occurrences. Cytherelloidea carnarvonensis was described from the Campanian Korojon calcarenite (Carnarvon Basin, western Australia).

Occurrences in Leg 122. Samples 122-762C-57X-3, 45-47 cm; $122-762 \mathrm{C}-66 \mathrm{X}-1,50-52 \mathrm{~cm}$; 122-761B-27X-1, 113-115 cm.

\section{Cytherelloidea cf. colemani Neale, 1975}

$$
\text { (PI. 1, Fig. 5) }
$$

Cytherelloidea colemani Neale, 1975, p. 5, pl. 4, figs. 2 and 3.

Length. $0.82 \mathrm{~mm}$.

Remarks. Only one specimen is present, having the general features of Cytherelloidea colemani, but Neale's species is smaller (0.61-0.62 mm).

Occurrences. Cytherelloidea colemani was described from the Santonian Gingin chalk (western Australia).

Occurrences in Leg 122. Sample 122-763B-8X-1, 88-90 cm.

\author{
Suborder PODOCOPINA Sars, 1866 \\ Superfamily BAIRDIACEA Sars, 1866 \\ Family BAIRDIIDAE Sars, 1866 \\ Genus BAIRDIA M'Coy, 1844 \\ Bairdia austracretacea Bate, 1972
}

(Pl. 1, Fig. 6)

Bairdia austracretacea Bate, 1972, p. 16, pl. 4, figs. 1, 2, 5, $8,11,12$, pl. 5 , fig. 6 .

Length. $1.21 \mathrm{~mm}$.

Occurrences. This species was described from the Campanian Korojon calcarenite and Toolonga calcilutite (Carnarvon Basin, western Australia).

Occurrences in Leg 122. Sample 122-763B-14X-3, 84-85 cm.
Bairdia sp.

(Pl. 1, Fig. 7)

Remarks. One carapace, belonging to the genus Bairdia, present in Sample 122-763B-29X-4, 90-93 cm, can be compared to Bairdia sp. D Oertli (1974) found in Albian levels from DSDP Leg 27, Site 260, pl. 3, fig. 9.

\section{Genus ROBSONIELLA Kusnetsova, 1956}

Robsoniella cf. falklandensis Dingle, 1984

$$
\text { (PI. 1, Fig. 8) }
$$

Robsoniella falklandensis Dingle, 1984, p. 118, fig. 8C-F.

Length. $0.68-0.70 \mathrm{~mm}$.

Remarks. These specimens show general features of Dingle's species, but are smaller, about $0.68-0.78 \mathrm{~mm}$, compared to $0.92-1.1$ $\mathrm{mm}$ for the type species.

Occurrences. Robsoniella falklandensis was described from the late Albian levels, DSDP Sites 327 and 330. Oertli recorded an identical species indet. gen. A in middle-upper Albian DSDP, Site 260, northwestern Australia.

Occurrences in Leg 122. Samples 122-762C-77X-4, 17-19 cm; 122-763B-29X-4, 90-93 cm; 122-763B-36X-3, 71-73 cm; 122-763B$38 \mathrm{X}-1,38-40 \mathrm{~cm} ; 122-763 \mathrm{~B}-39 \mathrm{X}-1,88-90 \mathrm{~cm}$.

\section{Family BYTHOCYPRIDIDAE Maddocks, 1969 Genus BYTHOCYPRIS Brady, 1880 \\ Bythocypris? cf. nodosa Brenner and Oertli, 1976}

$$
\text { (PI. 1, Fig. 9) }
$$

Bythocypris? nodosa Brenner and Oertli, 1976, p. 491, pl. 3, figs. $13-18$, pl. 7, fig. 25 .

Length. $0.40-0.42 \mathrm{~mm} ; 0.70-0.71 \mathrm{~mm}$.

Remarks. In the same sample, I find two groups of specimens attributed to the species nodosa, according to the external features. The first group has the same length, $0.40 \mathrm{~mm}$, as the typical species, while a second one is larger, with a $0.70-\mathrm{mm}$ length. The internal characteristics were not observed, so the generic assignment is doubtful. According to a reviewer's opinion, those specimens and also those attributed to "Bythocypris" cf. strogylae must be classified in the subfamily Paracypridinae.

Occurrences. Bythocypris? nodosa was described in Hauterivian levels of the Algoa Basin (South Africa).

Occurrences in Leg 122. Sample 122-763C-38R-1, 78-80 cm.

“Bythocypris” cf. strogylae Brenner and Oertli, 1976

$$
\text { (Pl. 1, Fig. 10) }
$$

"Bythocypris" strogylae Brenner and Oertli, 1976, p. 490, pl. 3, figs. $4-12$, pl. 7 , fig. 24.

Length. $0.57-0.65 \mathrm{~mm}$.

Remarks. The internal characteristics were not observed, so the generic assignment is doubtful. According to the general features those specimens may belong to the species strogylae.

Occurrences. "Bythocypris" strogylae was described in the Hauterivian of Algoa Basin (South Africa).

Occurrences in Leg 122. Samples 122-763C-13R-4, 89-91 cm; 122-763C-16R-2, 80-82 cm; 122-763C-20R-4, 55-57 cm.

Superfamily CYTHERACEA Baird, 1850 Family CYTHERIDAE Baird, 1850

Family SCHYZOCYTHERIDAE Mandelstam, 1960

Genus APATELOSCHIZOCYTHERE Bate, 1972

Apateloschizocythere geniculata Bate, 1972

(Pl. 1, Fig. 11)

Apateloschizocythere geniculata Bate, 1972, p. 30, pl. 7, figs. 5-8; pl. 8 , figs. $1-10$, pl. 15 , fig. 7 .

Apateloschizocythere geniculata Bate, Neale, 1973, p. 297.

Apateloschizocythere geniculata Bate, Neale, 1975, p. 38, pl. 9, fig. 8.

Length. $0.56-0.48 \mathrm{~mm}$.

Occurrences. Apatelochizocythere geniculata is present in the Campanian Toolonga calcilutite, in Campanian Korojon calcarenite, Carnarvon Basin, and in Santonian Gingin chalk (western Australia).

Occurrences in Leg 122. Samples 122-761B-25X-2, 18-20 cm; $122-762 \mathrm{C}-47 \mathrm{X}-4,63-65 \mathrm{~cm} ; 122-762 \mathrm{~B}-54 \mathrm{X}-4,148-150 \mathrm{~cm}$. 
Family PECTOCYTHERIDAE Hanai, 1957

Genus PARAMUNSEYELLA Bate, 1972, emend. Neale, 1975 Paramunseyella? exmouthensis $\mathrm{n} . \mathrm{sp}$.

(PI. 2, Figs. 1-5)

Derivation of name. From the Exmouth Plateau.

Holotype. A right valve (Pl. 2, Fig. 1) (collection Laboratoire de Micropaléontologie, Université Pierre et Marie Curie, number 1990 . 4).

Paratype. Five valves (numbers 1990-5, -6, -7, -8, and -9).

Type locality. Hole 762C, Leg 122, Sample 122-762C-47X-4, 63-65 $\mathrm{cm}$ (Exmouth Plateau).

Type level. Maestrichtian (calcareous nannofossil NK18 Zone).

Diagnosis. Species belonging with a query to the genus Paramunseyella. Carapace subrectangular, with coarsely pitted posterior shell surface, anterior shell surface smooth without ridges.

Dimensions. Holotype: length $=0.64 \mathrm{~mm}$, height $=0.37 \mathrm{~mm}$. Paratypes: length $=0.63-0.65 \mathrm{~mm}$, height $=0.37-0.40 \mathrm{~mm}$.

Description. Lateral view: Carapace subrectangular with broadly rounded anterior margin and narrow posterior end with some ventral denticles. Valve highest at the anterior cardinal angle, which is about one-third of the length. Region below slightly swollen anterior cardinal angle flattened and smooth. Dorsal margin straight, ventral margin slightly concave, no dorsal or ventral ridge. Surface punctuate only in posterior part, anterior and median parts smooth. Median part of the valve swollen especially ventrally. A slight ventral ridge follows a parallel course to the ventral surface and ends by curving upward on the posterior lateral surface. Left valve slightly larger than right one, which is overlapped only along the dorsal margin. Dorsal view: carapace broadly convex, with a flattened anterior end. Internal characteristics are difficult to observe. Hinge, left valve: two terminal sockets between a median ridge that seems to be larger posteriorly and perhaps also anteriorly.

Affinities and differences. Paramunseyella? exmouthensis shows the external features of the genus Paramunseyella, emended by Neale (1975) (e.g., without anterior margin ridge and deep furrow). But according to Bate's (1972) and Neale's (1975) descriptions, the genus Paramunseyella is smaller, with a length of about 0.45 to $0.50 \mathrm{~mm}$, than the species described here. Paramunseyella prideri Neale (1975) shows no ridge as this species does, but the entire shell is punctuate.

Paramunseyella? exmouthensis is very similar to Genus B of Bate (1972) but is larger and more rounded anteriorly. Bate indicates "weak-shelled species"-perhaps his specimen was a juvenile.

Occurrences in Leg 122. Samples 122-762C-47X-4, 63-65 cm; 122-762C-49X-2, 64-66 cm; 122-762C-53X-4, 15-17 cm; 122-762C$56 \mathrm{X}-6,37-39 \mathrm{~cm} ; 122-762 \mathrm{C}-57 \mathrm{X}-3,40-47 \mathrm{~cm} ; 122-763 \mathrm{~B}-14 \mathrm{X}-4$, $84-83 \mathrm{~cm} ; 122-761 \mathrm{~B}-24 \mathrm{X}-2,82-84 \mathrm{~cm} ; 122-764 \mathrm{~A}-5 \mathrm{R}-4,64-66 \mathrm{~cm}$.

\section{Family PROGONOCYTHERIDAE Sylvester-Bradley 1948 Genus MAJUNGAELLA Grekoff, 1963 \\ Majungaella nematis Grekoff, 1963}

(P1. 2, Fig. 7)

Majungaella nematis Grekoff, 1963, p. 1744, pl. V, figs. 141-145; pl. IX, figs. 213 and 232.

Neocythere uitenhagensis Dingle, 1969a, p. 152, fig. 11, figs. 14H, -I. Majungaella nematis Grekoff, Brenner, and Oertli, 1976, p. 501, pl. 5, figs. 11 and 12

Length. $0.60-0.62 \mathrm{~mm}$.

Remarks. The dimensions of the specimens present in Leg 122, as for those from the Algoa Basin (Brenner and Oertli, 1976), are smaller than those of the type species observed by Grekoff (1963) in the Majunga Basin (Madagascar).

Occurrences. In the Majunga Basin, Madagascar, Grekoff describes Majungaella nematis from the Portlandian-Valanginian levels. Brenner and Oertli recorded it in Hauterivian levels from Algoa Basin, South Africa.

Occurrences in Leg 122. Samples 122-763C-15R-2, 81-83 cm; 122-763C-17R-2, 80-82 cm; 122-763C-20R-4, 55-57 cm; 122-763C$25 \mathrm{R}-2,80-82 \mathrm{~cm}$.

\section{Majungaella sp. 20R}

(Pl. 2, Fig. 8)
Description. One valve, present in Sample 122-763C-20R-4, 55-57 $\mathrm{cm}$, may belong to the genus Majungaella. Small shell, subquadrate. Dorsal and ventral margins are straight, anterior margin broadly rounded, posterior margin more pointed. Surface of valve covered by an irregular network of bandlets that are ventrally parallel to the outline and posteriorly straight perpendicularly to the ventral ones. Internal characteristics: hinge, left valve: two terminals subdivided sockets, median ridge appears to be subdivided and larger anteriorly.

Remarks. This species shows the same ornamental pattern as Majungaella bifurcata Brenner and Oertli (1976) but is more rectangular and does not possess the characteristic branching of the ventrolateral rib of Majungaella bifurcata.

Occurrences in Leg 122. Sample $122-763 \mathrm{C}-20 \mathrm{R}-4,55-57 \mathrm{~cm}$

\section{Majungaella sp. 40R}

(Pl. 2, Figs. 9 and 10)

Length. $1.04 \mathrm{~mm}$.

Height. $0.64 \mathrm{~mm}$.

Short description and remarks. Large-sized species. Carapace subtrapezoidal, with rounded rim, dorsal margin straight and sloping gently downwards. Ventral margin straight, with overhanging lateral swelling. Surface ornamented by concentric ridges. Two anterior ridges begin behind the anterior dorsal angle, then run parallel to the anterior, ventral, and posterior rims. In the median zone of the valve, four or five other ridges are concentrically arranged. Internal characteristics: hinge entomodont. In left valve, two terminal sockets, a median bar subdivided and larger anteriorly. This hinge is the typical hinge of the genus Majungaella. No other Majungaella species described shows such a concentrical ridged pattern. The genus Centrocythere and Neocythere possess this type of ornamentation, but their hinges are quite different. As we have only one valve of this species, we cannot described it completely.

Occurrences in Leg 122. Sample 122-763C-40R-1, 80-82 cm.

\section{Subfamily COLLISABORIDAE Neale, 1975 \\ Genus COLLISABORIS Neale, 1975 \\ Collisaboris? stanleyensis Dingle, 1982}

(Pl. 2, Figs. 10-11)

Collisaboris? stanleyensis Dingle, 1982, p. 156 , fig. $23 \mathrm{E}$, -F, fig. 25 , fig. 26A.

Length. $0.56-0.62 \mathrm{~mm}$.

Occurrences. Collisaboris? stanleyensis was described in middlelate Albian DSDP 327, Falkland Plateau.

Occurrences in Leg 122. Samples 122-763B-27X-1, 38-40 cm, and 122-763B-29X-4, 90-93 cm.

\section{Family EUCYTHERURIDAE Puri, 1954 \\ Genus ARCULICYTHERE Grekoff, 1963 \\ Arculicythere tumida Dingle, 1971}

(PI. 3, Figs. 1 and 2)

Arculicythere tumida Dingle, 1971, p. 401, fig. 5.

Arculicythere sp. A Oertli, 1974, p. 947, pl. 4, figs. 1-11, Pl. 5, figs. 1-12.

Arculicythere tumida Dingle, Dingle, 1984, p. 153, fig. 22A-F, fig. $23 \mathrm{~A}-\mathrm{D}$.

Length. $0.59-0.55 \mathrm{~mm}$.

Remark. The genus Arculicythere is assigned to the family Eucytheruridae, according to Hartmann and Puri's (1974) classification.

Occurrences. According to Dingle (1984), Arculicythere tumida have the following range and geographical distribution: middle-upper Aptian of Aghulas Bank, South African continental margin; early to late Albian, DSDP Leg 36, Sites 327 and 330, Falkland Plateau; middle-upper Albian, DSDP Leg 27, Site 259, northwest of Perth, western Australia.

Occurrences in Leg 122. Samples 122-762C-77X-4, 17-19 cm; 122-763B-36X-3, 71-73 cm; 122-763B-39X-1, 88-90 cm.

\section{Arculicythere? sp. 17R}

(Pl. 3, Fig. 3)

Length. $0.63 \mathrm{~mm}$.

Length. $0.47 \mathrm{~mm}$ 
Short description and remarks. According to the external features and the hinge, this form is tentatively assigned to the genus Arculicythere. Valve subtriangular, with rounded anterior margin, and more pointed posterior margin. Dorsal and ventral ridge very slight as the subcentral tubercule and the median ridge. Shell surface smooth. Hinge, left valve: two terminal subdivided sockets and median bar (perhaps denticulated). Arculicythere tumida Dingle (1971) shows the same general outline, but has a spinous anterior margin; dorsal, median, and ventral ridges are thicker; the shell surface is ornamented.

Occurrences in Leg 122. Samples $122-763 \mathrm{C}-17 \mathrm{R}-2,80-82 \mathrm{~cm}$; $122-763 \mathrm{C}-25 \mathrm{R}-2,80-82 \mathrm{~cm}$.

\section{Arculicythere? sp. 46R}

(PI. 3, Fig. 4)

Length. $0.55 \mathrm{~mm}$.

Short description and remarks. This form is also tentatively assigned to the genus Arculicythere. Carapace subtriangular, anterior margin rounded, posterior margin more triangular. Dorsal ridge slight anteriorly, thicker posteriorly. Ventral ridge curving upward in an anterior ridge parallel to the anterior margin. Little, rounded subcentral tubercule. Median ridge reduced to an oval tubercule. Surface smooth with many rounded knobs.

Internal characteristics not observed; the generic assignment is thus doubtful.

No other Arculicythere species shows so many knobs. Arculicythere defluxa Grekoff, 1963, is more triangular with continuous dorsal and ventral ridges.

Occurrences in Leg 122. Sample 122-763C-46R-2, 36-40 cm.

Family SCHULERIDEINAE Mandelstam, 1959 Genus PIRILEBERIS Grekoff, 1963

Pirileberis sp. aff. P. mkuzensis Dingle, 1984

$$
\text { (Pl. 3, Fig. 5) }
$$

Aff. Pirileberis mkuzensis Dingle, 1984, p. 174, fig. 33B, -E.

Length. $0.65 \mathrm{~mm}$.

Short description and remarks. Carapace subtriangular to subrectangular. Rounded anterior margin, posterior margin acutely rounded with a ventral apex, specially in the left valve. Dorsal margin straight, slightly convex in left valve. Ventral margin gently convex. Left valve larger than the right one; in lateral view, the left valve overlaps the right one on all the margins. Surface of valve smooth. Internal characteristics not observed. This form is attributed to the genus Pirileberis according only to external features.

The general outline is the same as in Pirileberis mkuzensis, but $P$. sp. aff. $P$. mkuzensis has a stronger left valve overlap.

Occurrences. Pirileberis mkuzensis is described from Aptian to Albian levels of Zululand (South Africa).

Occurrences in Leg 122. Sample 122-763B-29X-4, 90-93 cm.

Family KRITHIDAE Mandelstam, 1958

Genus KRITHE Brady, Crosskey, and Robertson, 1874

Krithe sp. sp.

(PI. 3, Figs. 6-7)

Remarks. Some specimens belonging to the genus Krithe are found in the Upper Cretaceous. One of them (PI. 3, Fig. 6, Sample $122-762 \mathrm{C}-55 \mathrm{X}-2,140-142 \mathrm{~cm}$ ) can be compared to Krithe sp. shown in Bate's (1972) pl. 3, fig. 2.

Occurrences in Leg 122. Samples 122-762C-55X-2, 140-142 cm; $122-762 \mathrm{C}-64 \mathrm{X}-1,135-137 \mathrm{~cm} ; 122-762 \mathrm{C}-74 \mathrm{X}-1,74-76 \mathrm{~cm}$.

Family TRACHYLEBERIDIDAE Sylvester-Bradley 1948

Subfamily TRACHYLEBERIDINAE Sylvester-Bradley, 1948

Genus KARSTENEIS Pokorny, 1963

Subgenus KARSTENEIS Pokorny, 1963

Karsteneis (Karsteneis) aspericava Bate, 1972

(Pl. 3, Figs. 8-10)

Karsteneis (Karsteneis) aspericava Bate, 1972, p. 61, pl. 9, figs. 1-4; pl. 10 , figs. $1-4$; pl. 15 , fig. 4 .

Length. $0.99-1.03 \mathrm{~mm}$.

Remarks. The external features agree well with the original description of the species, but the type population is smaller: length = $0.77-0.88 \mathrm{~mm}$.
Occurrences. Karsteneis $(K$.$) aspericava is described in Santo-$ nian-Campanian Toolonga calcilutite and Koorojon calcarenite from the Carnarvon Basin (western Australia).

Occurrences in Leg 122. Samples 122-762C-49X-2, 64-66 cm; $122-764 \mathrm{~A}-5 \mathrm{R}-4,64-66 \mathrm{~cm}$.

\section{Genus OLIGOCYTHEREIS Sylvester-Bradley, 1948}

Oligocythereis? sp. 122

(Pl. 3, Figs. 11 and 12)

Length $0.75-0.76 \mathrm{~mm}$.

Short description and remarks. Species assigned to the genus Oligocythereis with query. Carapace subrectangular, with broadly rounded anterior margin and slightly rounded posterior margin. Dorsal and ventral margins straight. Greatest height at the well-developed anterior cardinal angle. Dorsal and ventral margin hidden by dorsolateral and ventrolateral ridges, dorsal ridge ending posteriorly in a vertical swelling. Strongly reticulate subcentral tubercule. Surface reticulate, especially in the median part, surface smooth just behind the anterior margin. In dorsal view, carapace somewhat rectangular, with compressed anterior zone and widest point at the subcentral tubercule. Internal characteristics: hinge, left valve: two subdivided teeth, median groove, perhaps subdivided. Marginal anterior zone rather large.

Affinities and differences. Oligocythereis? majungaensis Grekoff, 1963, (Portlandian from Majunga Basin, Madagascar) shows a more reticulate and spinose surface and a more prominent subcentral tubercule. Oligocythereis? dubia Dingle, 1972, (Upper Jurassic and Lower Cretaceous from South Africa) is more triangular with nodes.

Occurrences in Leg 122. Samples 122-763C-16R-2, 80-82 cm; $122-763 \mathrm{C}-19 \mathrm{R}-3,79-81 \mathrm{~cm} ; 122-763 \mathrm{C}-44 \mathrm{R}-3,78-80 \mathrm{~cm}$.

\section{Genus TRACHYLEBERIS Brady, 1858}

Trachyleberis anteplana Bate, 1972

$$
\text { (PI. 3, Fig. 13) }
$$

Trachyleberis anteplana Bate, 1972, p. 74, pl. 20, figs. 5-7, pl. 22, figs. $1-3$.

Length. $1.01-0.92 \mathrm{~mm}$.

Remarks. In these specimens, the general external features are the same as those of Trachyleberis anteplana. The general outline fits especially well Neale's figure $(1975$, p. 63 , text-fig. 13). The spine pattern and density are similar, although here the spines are more rounded and robust.

Occurrences. Trachyleberis anteplana is described in Campanian Toolonga calcilutite and Korojon calcarenite, Carnarvon Basin, western Australia.

Occurrences in Leg 122. Samples 122-761B-26X-2, 17-19 cm; 122-763B-16X-6, 15-17 cm.

\section{Genus MANDAWACYTHERE Bate, 1975 Mandawacythere sp. $763 \mathrm{C}$}

$$
\text { (Pl. 4, Figs. 1-4) }
$$

Length. $0.58-0.68 \mathrm{~mm}$.

Short description. Carapace subrectangular, rounded anterior margin, more pointed posterior margin. Dorsal margin straight, anterior cardinal angle distinct, and posterior cardinal angle less distinct. Long and straight ventral margin. Surface covered with very low longitudinal ridges, parallel to dorsal, anterior, and ventral margins, and confluent at the posterior end. In the median part of the valves, the ridges are lower, and in the anterior and posterior parts, some perpendicular connections are present between the ridges. Internal characteristics: hinge, left valve: long median bar (perhaps crenulate) and two low terminal teeth. An anterior vestibule is present. Muscle scars are not observed.

Remarks and affinities. This species presents many external and internal features of the genus Mandawacythere, described by Bate (1975) in the upper Kimmeridgian level of Tanzania (East Africa). Mandawacythere striata Bate (1975), the type species of the genus, is smaller (length $=0.37-0.43 \mathrm{~mm}$ ) and the lateral ridges possess connections between anterior and posterior parts of the ridges. The genus Pongolacythere Dingle (1984) shows the same general external features and ornamental pattern, but possess a paramphidont hinge. Two smaller specimens (Samples 122-763C-42R-2, 79-82 cm, and $122-763 \mathrm{C}-44 \mathrm{R}-6,76-79 \mathrm{~cm}$ ), one of which is depicted in Plate 4, 
Figure 4, have fewer lateral ridges. These forms appear to be juvenile instars, as considered by Bate (1975) for Mandawacythere striata (pl. 10, fig. 7). Bate assigns Mandawacythere to family Trachyleberididae, but this genus does not show the three typical longitudinal ridges of the family, nor the amphidont or merodont-entomodont hinge.

Occurrences in Leg 122. Samples 122-763C-17R-2, 80-82 cm; 122-763C-24R-2, 81-83 cm; 122-763C-36R-3, 99-102 cm; 122-763C44R-3, 78-80 cm; 122-763C-44R-6, 76-79 cm; 122-763C-45R-3, 118$120 \mathrm{~cm}$.

$$
\begin{gathered}
\text { Family PENNYELLIDAE Neale, } 1975 \\
\text { Genus PENNYELLA Neale, } 1974 \\
\text { Pennyella? sp. 11X } \\
\text { (Pl. 4, Fig. 5) }
\end{gathered}
$$

Length. $0.80 \mathrm{~mm}$.

Height. $0.47 \mathrm{~mm}$.

Short description. carapace subrectangular, with a rounded and spinose anterior margin. Ventral and dorsal margins straight. Dorsal ridges reduced to spines and ending in a short vertical posterior ridge. Ventral ridge ending in a posterior ventral spine. Subcentral tubercule and median ridge reduced. No eye tubercule. Surface covered by reticulation, with an anterior sulcus just behind the anterior margin. Internal characteristics: hinge, left valve: two terminal sockets and a median bar (not clearly observed).

Remarks and affinities. This species is tentatively assigned to the genus Pennyella. As does Pennyella, it possesses a vertical posterodorsal ridge, a posteroventral spine, an anterior (and perhaps posterior) sulcus just behind the marginal rim. Muscle scars and pore canals, characteristic of the genus, are not observed. Our species differs from Pennyella penny Neale (1974) in its larger size and more rounded posterior margin. Such a rounded posterior margin is a characteristic of Aghulasina quadrata Dingle (1971) but this species does not show a anterior sulcus.

Occurrences in Leg 122. Sample 122-763B-11X-2, 49-51 cm.

Family CYTHERURIDAE Mueller, 1894

Genus EUCYTHERURA Mueller, 1894

Eucytherura? aff. pyramidatus Dingle, 1981

(PI. 4, Fig. 6)

Aff. Eucytherura? pyramidatus Dingle, 1981, p. 43, fig. 19E.

Length. $0.41 \mathrm{~mm}$.

Short description and remarks. In lateral view, valve quadrate with broadly rounded anterior margin, acuminate posterior margin. Dorsal and ventral margins rather straight. A slight ventral lateral ridge runs from anterior quarter to a posteroventral process at three-quarters of the length. A pyramid-shaped posterodorsal process is located at the end of a short, poorly defined dorsal ridge. Valve surface coarsely reticulate with two anterior rims. Internal characteristics not observed. This species shows the general outline of Eucytherura? pyramidatus described by Dingle in Campanian levels from Zululand, South Africa, but true E.? pyramidatus is more reticulate. The internal features of these specimen are not observed, so the assignment to Eucytherurinae may be doubtful.

Occurrences in Leg 122. Sample 122-762C-47X-4, 63-65 cm.

$$
\begin{gathered}
\text { Genus PROCYTHERURA Whatley, } 1970 \\
\text { Procytherura sp. 16R }
\end{gathered}
$$$$
\text { (Pl. 4, Fig. 7) }
$$

Length. $0.55 \mathrm{~mm}$.

Short description and remarks. Carapace subrectangular, with a broadly rounded anterior margin, straight dorsal margin. Pointed posterior margin. Ventral margin slightly curved in its central part, a small keel is present ending posteriorly in a little knob. Surface of valves ornamented by a slight reticulation in the posterior part of the valve. A little ridge runs parallel to the ventral part of the anterior margin, and then curves parallel to the ventral margin. This species shows the external lateral features of Procytherura maculata Brenner and Oertli (1974) (Hauterivian from Algoa Basin, South Africa), but does not possess the characteristic dimple pattern on the surface of the valve.

Occurrences in Leg 122. Samples $122-763 \mathrm{C}-15 \mathrm{R}-2,80-83 \mathrm{~cm}$; 122-763C-16R-2, 80-83 cm.
Family CYTHEROPTERIDAE Hanai, 1957 Genus EOCYTHEROPTERON Alexander, 1933

Eocytheropteron cf. corrosum (Grekoff, 1963)

(Pl. 4, Figs. 8-9)

Cf.Cytheropteron corrosum Grekoff, 1963, p. 1277, pl. II, figs. 39-41. Eocytheropteron cf. corrosum (Grekoff) McLachlan, Brenner, and McMillan, 1976, p. 366, fig. 16, no. 17.

Length. $0.46 \mathrm{~mm}$.

Remarks. Our form shows the external features of Grekoff's species. However, here the pits are bigger and less numerous, and just behind the anterodorsal angle there is a slight protuberance. As no internal characteristics were observed, the generic attribution is doubtful.

Occurrences. Cytheropteron corrosum was described in the Portlandian level from Madagascar. McLachlan et al. (1976a) found Eocytheropteron $\mathrm{cf}$. corrosum in the Valanginian Brenton Formation, South Africa.

Occurrences in Leg 122. Sample 122-763C-38R-1, 78-80 cm.

Genus CYTHEROPTERON Sars, 1866

Cytheropteron? sp. $30 \mathrm{R}$

(Pl. 4, Figs. 10-11)

Length. $0.50 \mathrm{~mm}$.

Height. $0.28 \mathrm{~mm}$.

Short description. Lateral view: carapace small with rounded anterior margin and more pointed posterior margin. Dorsal margin rather straight, ventral margin straight anteriorly, curved upwards posteriorly. Short posterodorsal ridge, curved posteriorly. Long median ridge, beginning just behind the anterior rim and ending at three-quarters of the length. Ventral ridge beginning also just behind the anterior rim; this ventral ridge ends at three-quarters of the length. Surface smooth with some punctuation.

Dorsal view: subtriangular carapace with a posterior keel. At three-quarters of the length, the ventral margin draws the larger width of the carapace. Internal characteristics not observed.

Remarks and affinities. According to the external features this species is tentatively assigned to the genus Cytheropteron, but this form can also belong to family Schizocytheridae.

In lateral view, this species can be compared to Annosacythere? sp. A Brenner and Oertli (1976), which shows the same three lateral ridges, but with the median one divided.

Occurrences in Leg 122. Sample 122-763C-30R-2, 80-82 cm.

Family UNCERTAIN

Genus HYSTRICOCYTHERE Bate, 1972

Hystricocythere? sp.

(PI. 4, Fig. 12)

Length. $0.59 \mathrm{~mm}$.

Short description and remarks. Three broken valves are assigned to the genus Hystricocythere with a query. Small form, with straight dorsal margin, pointed posterior margin, and straight ventral margin with a slight median constriction. Surface reticulate and spinose as for the type species. The concentric reticulation is not so clear, however, as in Hystricocythere imitata Bate (1972).

Occurrences in Leg 122. Samples 122-761B-27X-1, 115-117 cm; $122-762 \mathrm{C}-56 \mathrm{X}-6,37-39 \mathrm{~cm} ; 122-763 \mathrm{~B}-13 \mathrm{X}-1,80-82 \mathrm{~cm}$.

$$
\begin{aligned}
& \text { INCERTAE SEDIS } \\
& \text { Genus X sp. } \\
& \text { (Pl. 4, Figs. 13-15) }
\end{aligned}
$$

Length. $0.80 \mathrm{~mm}$.

Height. $0.50 \mathrm{~mm}$.

Short description. Subrectangular reticulate carapace. Rounded anterior margin with a rather large smooth rim. Triangular posterior margin also with a smooth rim. Fairly distinct subcentral tubercule, no median ridge. Ventral and dorsal ridges reduced to small development of wall's reticulation. In dorsal view, carapace subrectangular with lightly compressed anterior zone. Internal characteristics not observed. A similar, but smaller form is present (Sample 122-762C-59X-4, 56-58 cm, Pl. 4, Fig. 15), with a length of $0.48 \mathrm{~mm}$, having a narrower anterior rim. This form may be a juvenile instar of the same species. 
Remarks and affinities. This form may belong to the genus Limburgina Deroo (1966) but Limburgina possesses a more prominent cardinal angle and a more spinose ornamentation. Oertliella and especially Oertliella sp. 476 Dingle (1980) from the Santonian and the Campanian of South Africa, are more spinose and do not possess a large, smooth anterior rim.

Occurrences in Leg 122. Samples $122-762 \mathrm{C}-54 \mathrm{X}-4,148-150 \mathrm{~cm}$; $122-762 \mathrm{C}-59 \mathrm{X}-4,56-58 \mathrm{~cm}$.

\section{CONCLUSION}

Two major faunal assemblages exist in the Cretaceous ostracode fauna present in cores from Leg 122 .

During the Lower Cretaceous (Berriasian to Albian), the ostracode assemblages are similar to the South Gondwana fauna of Dingle (1988) with the presence of Majungaella sp., Majungaella nematis, Arculicythere sp., Arculicythere tumida, and Pirileberis. These Lower Cretaceous ostracodes show affinities with South African and Madagascar faunas.

In the Upper Cretaceous levels (Santonian to Maestrichtian), the recorded ostracodes will belong to the Para-Gondwana Fauna, but only one characteristic form of this fauna is present in cores from Leg 122: Apateloschizocythere geniculata. In the Para-Gondwana Fauna, Dingle (1988) established two faunas: fauna C (Turonian-Santonian) and fauna D (Campanian-Maestrichtian). Because of the lack of data about Turonian-Coniacian ostracodes, the Leg 122 fauna can be compared with fauna D. In Leg 122 cores, CampanianMaestrichtian ostracodes seem more endemic to the Australian areas than in Lower Cretaceous. Of particular importance is the absence of the genus Brachycythere. Dingle (1988, p. 847) states "recognition of the Para-Gondwana Fauna in South and East Africa and India can be simplified to the arrival of Brachycythere and an upsurge of trachyleberid taxa." As this genus and other well-known South African trachyleberids are absent, the attribution of the Upper Cretaceous Leg 122 fauna to the Para-Gondwana Fauna is still tentative, and the Lower Cretaceous fauna studied belongs to South Gondwana Fauna.

\section{ACKNOWLEDGMENTS}

I thank the staff of the Ocean Drilling Program for the opportunity to study samples from Leg 122 . I am greatly indebted to R. H. Bate, R. V. Dingle, and J. W. Neale for sending me their very useful publications. I acknowledge the four reviewers for their helpful criticism and especially for their suggestions to improve the language.

\section{REFERENCES}

Bate, R. H., 1972. Upper Cretaceous Ostracoda from the Carnarvon Basin, Western Australia. Spec. Pap. Paleontol., 10:1-85. 1975. Ostracods from Callovian to Tithonian sediments of Tanzania, East Africa. Bull. Br. Mus. (Nat. Hist.), Geol., 26:161223.

Bate, R. H., and Bayliss D. D., 1969. An outline account of the Cretaceous and Tertiary foraminifera and of the Cretaceous ostracods of Tanzania. Proc. Third Afr. Coll. (Cairo), 113-169.

Bertels, A., 1974. Upper Cretaceous (lower Maastrichtian?) ostracodes from Argentina. Micropaleontology, 20:385-397.

, 1975. Upper Cretaceous (middle Maastrichtian) ostracodes of Argentina. Micropaleontology, 21:97-130.

1977. Estatigrafia y micropaleontologia de la formacion San Julian en su area typo, Provincia de Santa Cruz, Republica Argentina. Ameghiniana, 14:233-293. $34: 259$.
Brenner, P., and Oertli, H. J., 1976. Lower Cretaceous Ostracodes (Valanginian to Hauterivian) from the Sundays river formation, Algoa Basin, South Africa. Bull. Cent. Rech. Pau, 10:471-533.

Dingle, R. V., 1969a. Marine Neocomian Ostracoda from South Africa. Trans. R. Soc. S. Afr., 38:139-164. $1969 \mathrm{~b}$. Upper Senonian ostracodes from the Coast of Pondoland, South Africa. Trans. R. Soc. S. Afr., 38:347-385. 1971. Some Cretaceous ostracodal assemblages from the Agulhas Bank (South African continental margin). Trans. R. Soc. S. Afr., 39:393-418, 16 fig., 1 pl. 1976. Paleogene Ostracods from the continental shelf off Natal, South Africa. Trans. R. Soc. S. Afr., 42:35-79. 1980. Marine Santonian and Campanian Ostracods from a borehole at Richards bay, Zululand. Ann. S. Afr. Mus., 82:1-70. 1981. The Campanian and Maastrichtian Ostracoda of South-East Africa. Ann. S. Afr. Mus., 85:1-181. 1982. Some aspects of Cretaceous Ostracod biostratigraphy of South Africa and relationships with other Gondwanide localities. Cretaceous Res., 3:367-389. 1984. Mid-Cretaceous Ostracoda from Southern Africa and the Falkland Plateau. Ann. S. Afr. Mus., 93:97-211. 1985. Turonian, Coniacian and Santonian Ostracoda from South-East Africa. Ann. S. Afr. Mus., 96:123-239. 1988. Marine Ostracod distributions during the early breakup of Southern Gondwanaland. In Hanai, T., et al. (Eds.), Evolutionary, Biology, of Ostracoda. Dev. in Paleontol. and Stratigraphy. Amsterdam (Elsevier), 11:841-854.

Grekoff, N., 1963. Contribution à l'étude des Ostracodes du Mésozoïque moyen (Bathonien-Valanginien) du bassin de Majunga, Madagascar. Rev. Inst. Fr. Pet., 12:1709-1783.

Haq, B. U., von Rad, U., O'Connell, S., et al., 1990. Proc. ODP, Init. Repts., 122: College Station, TX (Ocean Drilling Program).

Hartmann, G., and Puri, H. S., 1974. Summary of neontological and paleontological classification of Ostracoda. Mitt. Hamburg. Zool. Mus. Inst., 70:7-73.

Krömmelbein, K., 1975. Ostracoden aus der Kreide des Great Artesian Basin, Queensland, Australien. Senckenbergiana Lethaea, 5:455-483, 5 pl.

McLachlan, I. R., Brenner, P. W., and McMillan, I. K., 1976a. The stratigraphy and micropaleontology of the Cretaceous Brenton formation and the PB-A/1 well, near Knysna, Cape Province. Trans. Geol. Soc. S. Afr., 79:341-370.

McLachlan, I. R., McMillan, I. K., and Brenner, P. W., 1976b. Micropaleontogical study of the Cretaceous beds at Mbotyi and Mngazna, Transkei, South Africa. Trans. Geol. Soc. S. Afr., 79:321-340.

Neale, J. W., 1973. On Apateloschizocythere geniculata Bate. StereoAtlas of Ostracod Shells, 1:297-304.

1974. On Pennyella pennyi gen. et $\mathrm{sp}$. nov. Stereo-Atlas of Ostracod Shells, 2:125-132.

1975. The Ostracod Fauna from the Santonian chalk (Upper Cretaceous) of Gingin, Western Australia. Spec. Pap. Paleontol., 16:1-81.

Oertli, H. J., 1974. Cretaceous and Jurassic ostracods from DSDP Leg 127: a preliminary account. In Veevers, J. J., Heirtzler, J. R., et al., Init. Repts. DSDP, 27: Washington (U.S. Govt. Printing Office), 947-965.

Sigal, J., 1974. Comments on Leg 25 sites in relation to the Cretaceous and Paleogene stratigraphy in the eastern and southeastern African and Madagascar regional setting. In Simpson, E.S.W., Schlich, R., et al., Init. Repts. DSDP, 25: Washington (U.S. Govt. Printing Office), 687-723.

Date of initial receipt: 7 March 1990 Date of acceptance: 25 January 1991 Ms 122B-175 


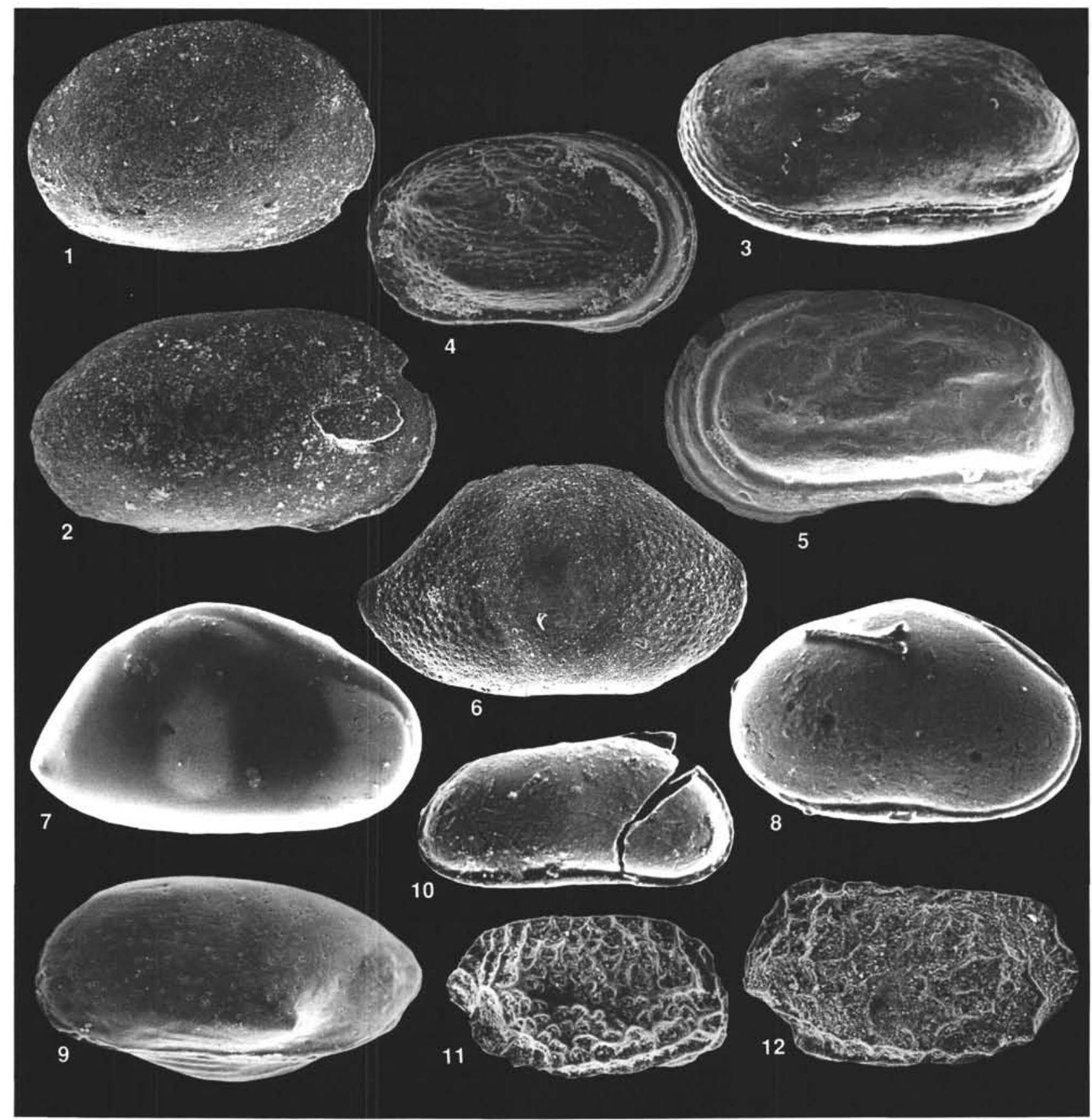

Plate 1. Cretaceous ostracodes, Leg 122. 1. Cytherella $\mathrm{cf}$. atypica Bate, 1972; 75×, right valve, Sample 122-762C-55X-2, 140-142 cm. 2. Cytherella bensoni Dingle, 1984; 75×, carapace from the left, Sample 122-762C-77X-4, 17-19 cm. 3. Cytherella cf. jonesi Neale, 1975; $75 \times$, right valve, Sample 122-763B-9X-1, 80-82 cm. 4. Cytherelloidea cf. carnarvonensis Bate, 1972; 75 $\times$, right valve (perhaps juvenile), Sample 122-762C-66X-1, 50-52 cm. 5. Cytherelloidea cf. colemani Neale, 1975; 75×, left valve, Sample 122-763B-8X-1, 88-90 cm. 6. Bairdia austracretacea Bate, 1972; 50×, right valve, Sample 122-763B-14X-3, 84-85 cm. 7. Bairdia sp.; 75×, carapace from right, Sample 122-763B-29X-4, 90-93 cm. 8. Robsoniella cf. falklandensis Dingle, 1984; 75×, carapace from right, Sample 122-763B-38X-1, $38-40 \mathrm{~cm}$. 9. Bythocypris? cf. nodosa Brenner and Oertli, 1976; 90×, carapace from the left, Sample 122-763C-38R-1, 78-80 cm. 10. "Bythocypris" cf. strogylae Brenner and Oertli, 1976; 75×, carapace from right, Sample 122-763C-13R-4, 89-91 cm. 11, 12. Apateloschizocythere geniculata Bate, 1972; 90×, (11) right valve, Sample 122-761B-25X-2, 18-20 cm; (12) left valve, Sample $122-762 \mathrm{C}-47 \mathrm{X}-4,63-65 \mathrm{~cm}$. 


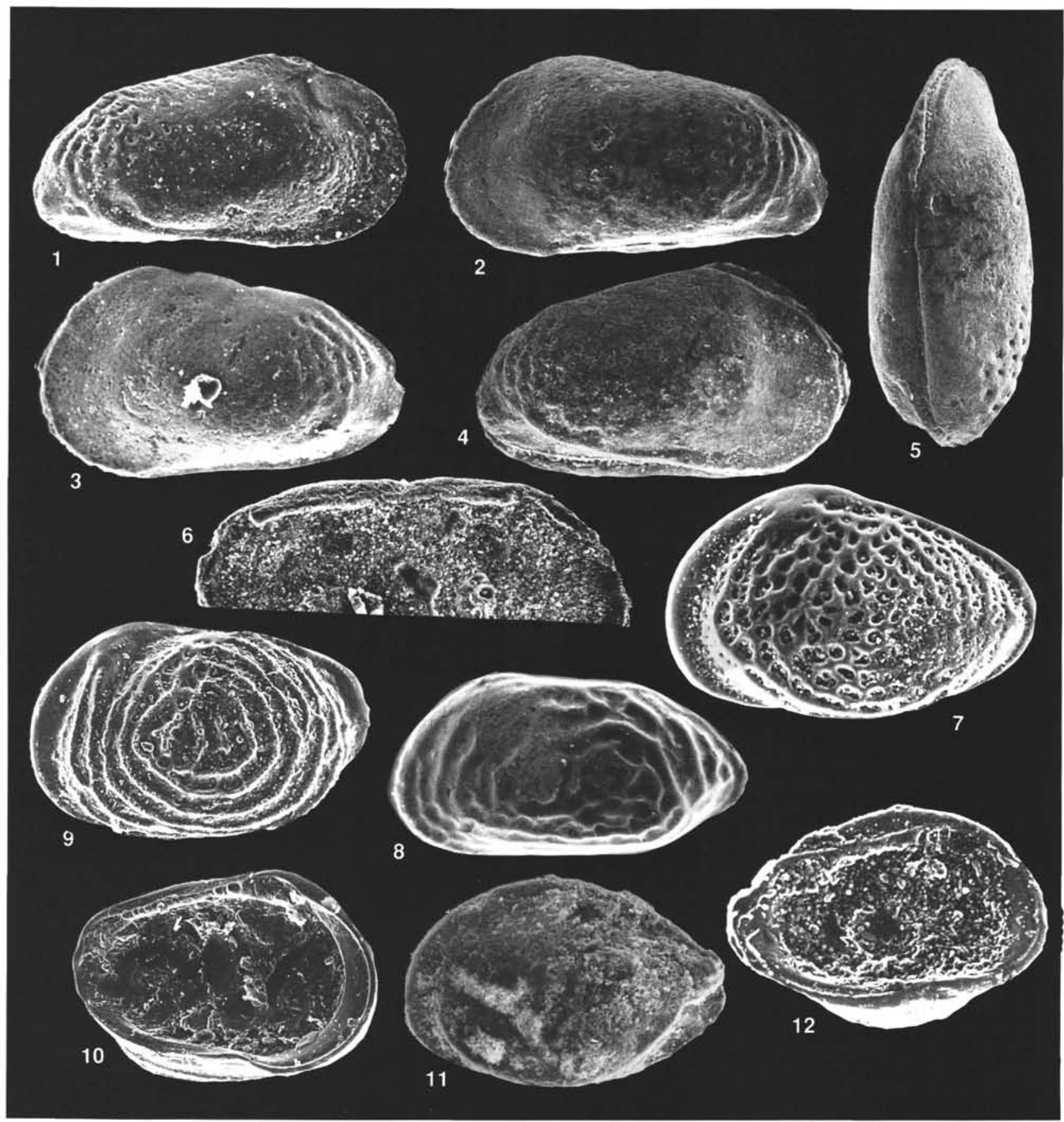

Plate 2. Cretaceous ostracodes, Leg 122. 1-6. Paramunseyella? exmouthensis n. sp.; (1-5) $90 \times$, (1) right valve, holotype; (2) left valve; (3) left valve; (4) carapace from right; (5) carapace, dorsal view; (6) left valve (part), internal view; (1, 2, 6) Sample 122-762C-47X-4, 63-65 cm; (3, 5) Sample 122-762C-49X-2, 64-66 cm; (4) Sample 122-762C-53X-4, 15-17 cm. 7. Majungaella nematis Grekoff, 1963; $90 \times$, left valve, Sample 122-763C-17R-2, 80-82 cm. 8. Majungaella sp. 20R; 90×, left valve, Sample 122-763C-20R-4, 55-57 cm. 9, 10 . Majungaella sp. 40R; 50×, (9) right valve; (10) right valve, internal view; $(9,10)$ Sample $122-763 \mathrm{C}-40 \mathrm{R}-1,80-82 \mathrm{~cm}$. 11, 12. Collisaboris? stanleyensis Dingle, 1982; $90 \times$, (11) left valve; (12) left valve, internal view; $(11,12)$ Sample 122-763B-27X-1, 38-40 cm. 


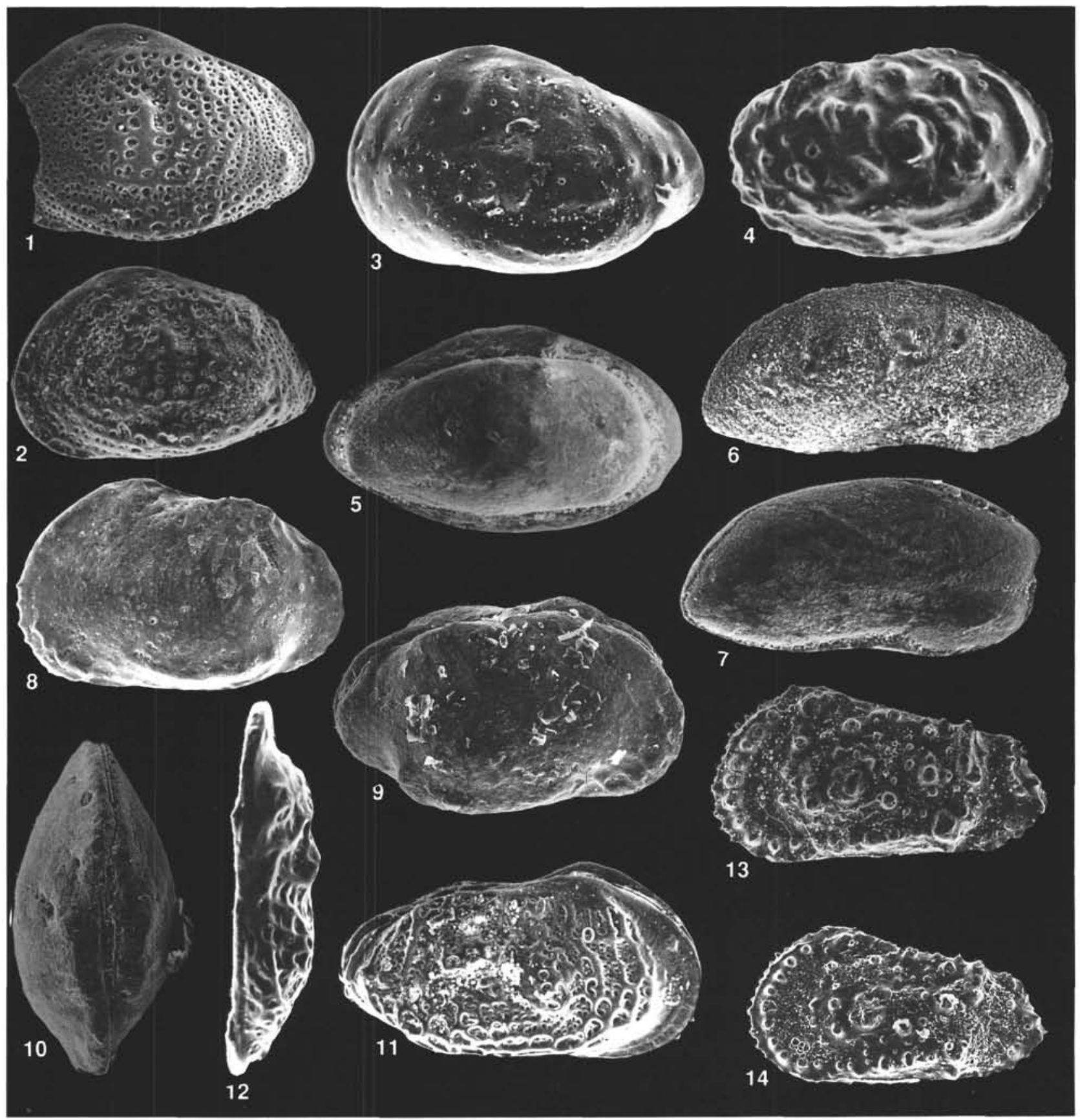

Plate 3. Cretaceous ostracodes, Leg 122. 1, 2. Arculicythere tumida Dingle, 1971; 90X, (1) left valve, Sample 122-763B-36X-3, 71-73 cm; (2) left valve, Sample 122-763B-39X-1, 88-90 cm. 3. Arculicythere sp. 17R; 90×, left valve, Sample 122-763C-17R-2, 80-82 cm. 4. Arculicythere sp. 46R; $90 \times$, carapace from right, Sample 122-763C-46R-2, 36-40 cm. 5. Pirileberis sp. aff. P. mkuzensis Dingle, 1984; $97 \times$, carapace from right, Sample 122-763B-29X-4, 90-93 cm. 6, 7. Krithe spp.; (6) $90 \times$, carapace from right, Sample 122-762C-55X-2, 140-142 cm; (7) 75×, carapace from right, Sample 122-762C-64X-1, 74-76 cm. 8-10. Karsteneis aspericava Bate, 1972; 50×, (8) left valve; (9) carapace from right; (10) carapace, dorsal view; (8-10) Sample 122-762C-49X-2, 64-66 cm. 11, 12. Oligocythereis? sp. 122; $75 \times$, (11) carapace from right, Sample 122-763C-16R-2, 80-82 cm; (12) right valve, dorsal view, Sample 122-763C-44R-3, 78-80 cm. 13, 14. Trachyleberis anteplana Bate, 1972; 50×, (13) left valve, Sample 122-761B-26X-2, 17-19 cm; (14) left valve, Sample 122-763B-16X-6, $15-17 \mathrm{~cm}$. 


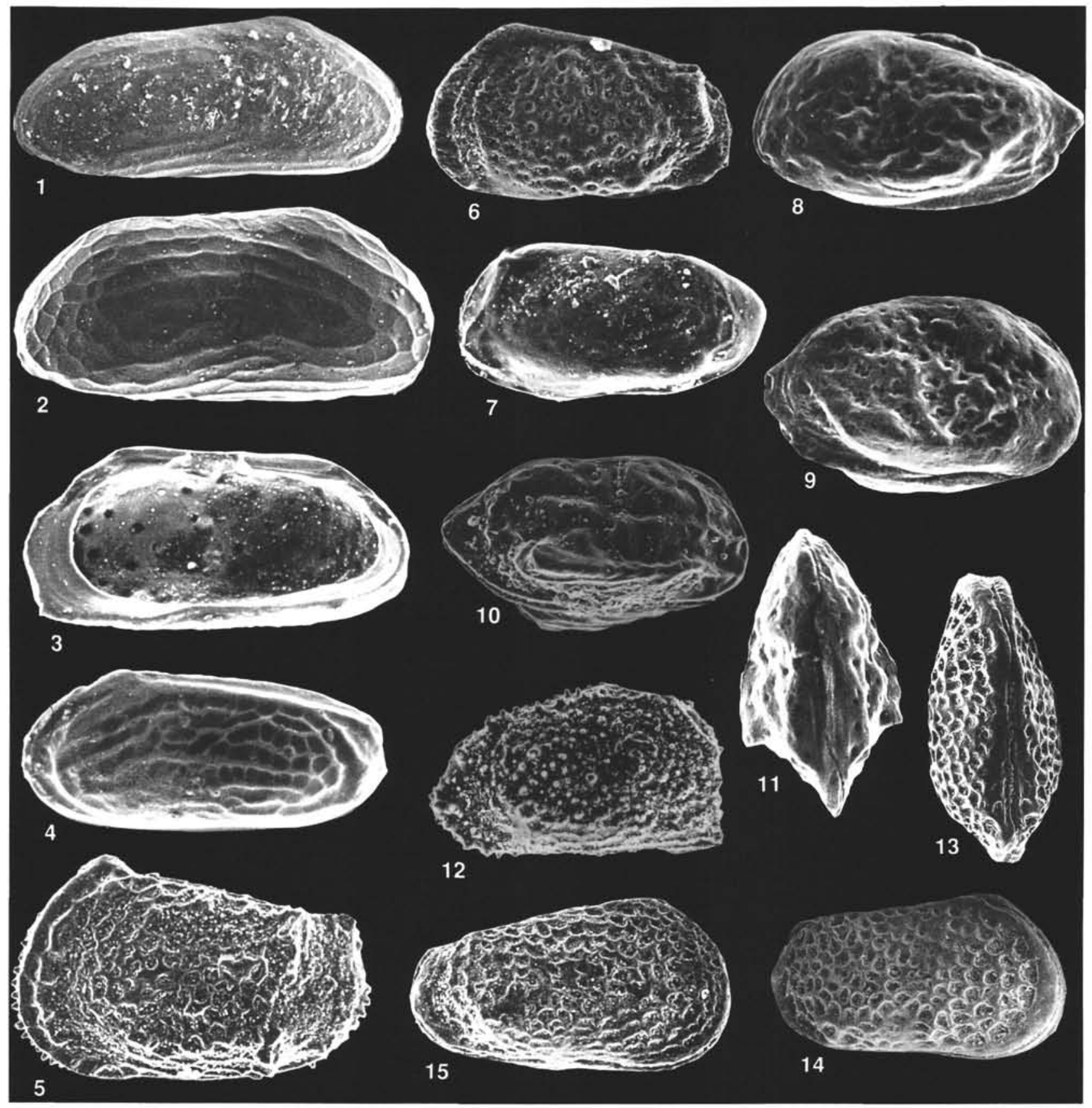

Plate 4. Cretaceous ostracodes, Leg 122. 1-4. Mandawacythere sp. 763C; (1) 90×, right valve, Sample 122-763C-24R-2, 81-83 cm; (2) $90 \times$, right valve, Sample 122-763C-45R-3, 118-120 cm; (3) $90 \times$, left valve, internal view, Sample 122-763C-45R-3, 118-120 cm.; (4) $105 \times$, carapace, from left, Sample 122-763C-44R-6, 76-79 cm. 5. Pennyella? sp. 11X; 75×, left valve, Sample 122-763B-11X-2, 49-51 cm. 6. Eucytherura aff. pyramidatus Dingle, 1981; 105×, left valve, Sample 122-762C-47X-4, 63-65 cm. 7. Procytherura sp. 16R; 90×, carapace, from right, Sample 122-763C-16R-2, 80-83 cm. 8, 9. Eocytheropteron cf. corrosum (Grekoff, 1963); 105×, (8) carapace from left; (9) carapace from right; $(8,9)$ Sample $122-763 \mathrm{C}-38 \mathrm{R}-1,78-80 \mathrm{~cm}$. 10, 11. Cytheropteron sp. 30R; 90×, (10) carapace from right; (11) carapace, dorsal view; $(10,11)$ Sample $122-763$ C-30R-2, 80-82 cm. 12. Hystricocythere? sp.; $75 \times$, right valve (broken), Sample 122-763B-13X-1, 80-82 cm. 13-15. Genus X sp.; (13) 50×, carapace dorsal view; (14) 50×, carapace from left; (13, 14) Sample $122-762 \mathrm{C}-54 \mathrm{X}-4,158-150 \mathrm{~cm}$; (15) $90 \times$, carapace from right, Sample $122-762 \mathrm{C}-59 \mathrm{X}-4,56-58 \mathrm{~cm}$. 